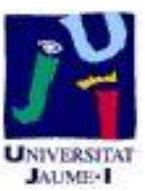

Título artículo / Títol article: A guide for supply chain integration in SMEs

Autores / Autors

Sergio Palomero Ródenas

Ricardo Chalmeta Rosaleñ

Revista:

Production Planning \& Control: The Management of Operations Volume 25, Issue 5, 2014

Versión / Versió:

Pre-print

Cita bibliográfica / Cita bibliogràfica (ISO 690):

url Repositori UJI:
PALOMERO, Sergio; CHALMETA, Ricardo. A guide for supply chain integration in SMEs. Production Planning \& Control, 2014, vol. 25, no 5, p. 372-400.

http://hdl.handle.net/10234/128151 


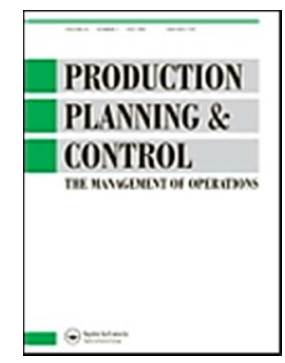

\section{A Guide for Supply Chain Integration in SMEs}

\begin{tabular}{|r|l|}
\hline Journal: & Production Planning \& Control \\
\hline Manuscript ID: & TPPC-2009-0095.R5 \\
\hline Manuscript Type: & Industrial Applications \\
\hline Date Submitted by the Author: & $\mathrm{n} / \mathrm{a}$ \\
\hline Complete List of Authors: & $\begin{array}{l}\text { Palomero Rodenas, Sergio; Universidad Jaume I, } \\
\text { Chalmeta, Ricardo; Universidad Jaume I, }\end{array}$ \\
\hline Keywords: & $\begin{array}{l}\text { Supply Chain Integration (SCI), Case Study, SME, } \\
\text { Measurement/Methodology, KPI }\end{array}$ \\
\hline
\end{tabular}

SCHOLARONE ${ }^{m}$

Manuscripts

URL: http://mc.manuscriptcentral.com/tppc E-mail: ppc@exeter.ac.uk 


\title{
A Guide for Supply Chain Integration in SMEs
}

\author{
Sergio Palomero, Ricardo Chalmeta* \\ Grupo Integración y Re-Ingeniería de Sistemas \\ Dept. Lenguajes y Sistemas Informáticos \\ Universitat Jaume I, Campus Riu Sec s/n, 12071 Castellón, Spain \\ Phone: 34964 728435; Fax: 34964728435 \\ \{palomero, rchalmet\}@uji.es
}

\begin{abstract}
Ricardo Chalmeta Rosaleñ is an associate professor in the Computer Science Department at the Universitat Jaume I in Castellón, Spain. He is Head of the Systems Integration research group (IRIS group) at this university. He received his $\mathrm{BSc}$, MSc and $\mathrm{PhD}$ degrees in Computer Engineering from the Universidad Politécnica de Valencia, Spain. He has been invited as a researcher and lecturer by different universities such as Griffith University (Australia), Purdue University (USA), the University of Sao Paulo (Brazil), the University of Osnabruck (Germany), the University of Lima (Peru) or the University of National and World Economy (Bulgaria). He has served as a consultant in several manufacturing and transport firms, working on Enterprise Integration and Re-engineering activities and on the development of Integrated Information Systems. His research interests include Enterprise Integration, Re-engineering, Information Systems, Electronic Commerce, Workflow Modelling and Simulation.
\end{abstract}

Sergio Palomero Rodenas has been an associate professor in the Computer Science Department at the Universitat Jaume I in Castellón, Spain. He was a member of the Systems Integration research group (IRIS group) at this university. He earned a Master's Degree in Business Administration and a PhD in Industrial Engineering from the Universidad Politécnica de Valencia, Spain. He was Head of the Department of Production Engineering at the GEC-Alsthom Transport Factory in Valencia and is in charge of SAP installation in the production area of all the Spanish factories in the Alsthom Group. He has served as a consultant in several manufacturing firms, working on Enterprise Integration and Re-engineering activities and on the development of Integrated Information Systems. He is currently working on different research projects, such as the project entitled Architecture to Support Enterprise Interoperability Projects or the Methodology to Support SCM in SMEs project. His research interests include Enterprise Integration, Re-engineering, Information Systems, Electronic Commerce, Modelling and Simulation, Workflow and Open Innovation. Now he is an associate professor in the Business Administration Department and member of the Excellentia Research Group at the Universitat Jaume I.

\footnotetext{
* Corresponding author: Ricardo Chalmeta, Universitat Jaume I, Av. de Vicent Sos Baynat, s/n. 12071 Castelló de la Plana, Spain. Tel:+34 964 $728329 ;$ Fax: +34 964 728435 ; email: rchalmet@uji.es
} 


\section{Abstract}

Supply Chain Integration (SCI) is a competitive business approach for enterprises that has not been implemented as widely as expected in small and medium-sized enterprises (SMEs). One of the factors explaining this low level of application is the lack of methodologies to develop Supply Chain Integration that fit the characteristics of this type of enterprise.

In this paper we present a methodology that enables SMEs to achieve correct supply chain integration in a manner that is simple, straightforward and oriented towards their particular characteristics. Thus, SMEs will be able to align and coordinate the aims, resources, decisions, methods, business process and employees involved in the supply chain.

The methodology addresses the problem of SMEs supply chain integration and it was produced by applying the case study research method to 30 industrial SMEs. The methodology is organised in phases and the activities to be performed, the techniques and supporting tools to be used, as well as the expected outcomes are all described for each phase. With this methodology it becomes possible to overcome the main barriers that prevent SMEs from achieving a correct integration of their supply chains. In addition to the methodology, the paper also outlines the significant benefits observed in the 30 enterprises as a result of its application.

Keywords: Supply Chain Integration (SCI), SME, Case Study, Logistics, Measurement/Methodology, KPI.

\section{Introduction}

To remain competitive, enterprises have begun to rethink many of the management models that, until now, they have considered valid. This change in outlook can be explained by a number of different factors, the most important of which include: (1) the fact that enterprises are finding themselves almost forced to open up to international markets due to the phenomenon of globalisation; (2) the increasing demand from customers for a greater variety of products, with a high level of quality, short delivery times, very competitive prices and high quality after-sales service; (3) the new possibilities in business management afforded by computer support tools; and (4) the deep recession suffered by financial markets around the world.

Within this framework, one of the areas in which important efforts are being made to cut costs and improve efficiency is in the relations the firm has with its stakeholders in the supply chain (Ballou 2004). Supply Chain Management (SCM) has therefore become a strategic goal and is now seen as a key competitive factor (Tan et al. 2002) that is essential to be able to compete in markets that are increasingly more global, dynamic and aggressive (Giunipero et al. 2006).

One of the fundamental aspects involved in accomplishing SCM is to achieve supply chain integration (SCI) (Forker et al. 1997), which consists in aligning and coordinating the resources, decisions, methods, business processes and employees of the different stakeholders in the supply chain to improve their ability to work together in a continuous improvement process (Chalmeta and Grangel 2003).

SCI is one of the most significant challenges in the modern management of SMEs (Gélinas and Bigras 2004) and, as reported by Chen et al. (2004), yields different kinds of benefits that include reduced costs, increased revenue, enhanced (end) customer satisfaction, improved on-time delivery, reduced supply chain costs, reduced time in the provisioning and quality control processes, reduced 
work in process and final products stocking, automated processes, standardised production, improved payment process, improved distribution process and improved global competitiveness, improved services, improved quality, improved pipeline visibility (that is the visibility of each of the activities of the Supply Chain by each of the partners), and Improved demand visibility by each of the partners, and so forth.

SMEs are defined as "Enterprises which employ fewer than 250 persons and which have an annual turnover not exceeding 50 million euro, and/or an annual balance sheet total not exceeding 43 million euro" (European Commission 2003). This need for SMEs to manage their supply chains in a suitable manner and achieve a high degree of integration can also sometimes be imposed from outside by the large enterprises that the SMEs, where small businesses act as an ancillary or 1st and 2nd tier suppliers in their supply chain (Thakkar et al. 2008) or as subcontracted firms, because integration is essential to these large firms in order for them to become more efficient.

As Tan et al. (2006) state, given the limited resources within SMEs, they would reap more benefits from greater efforts to integrate with other SMEs, since they can then tap into each other's expertise. SCI is therefore one of the most prevalent issues facing SMEs (Lewis 2005).

From our experience in SCI in real-world situations and in accordance with other authors, like Vaaland et al. (2007), Thakkar et al. (2009) or Quayle (2003), who highlight the common weaknesses found in SCI methods in practice, supply chain integration in SMEs has received little attention in comparison to large enterprises (LE). Thakkar et al. (2008) identified the main reasons explaining this lack of integration in the supply chains of SMEs with respect to LEs as the following: (1) the lack of internal integration in SMEs (Singh 1998); (2) lack of understanding on merits and demerits of alliances (Power 2006); (3) poor use of IT (Ritchie and Brindley 2000); (4) immature buyer-supplier relationship (Arend and Winser 2005); (5) absence of performance measurement (Quayle 2002, 2003); and (6) poor strategic vision (Oakes and Lee 1999, Harland et al. 2007).

However, despite the scarcity of supply chain integration in SMEs, SCI research tends to be focused more towards large-scale organisations. This shortage of research studies that analyse SCI from the perspective of SMEs is confirmed by authors such as Sastry (1999), who identified the fact that research has focused more on the supply chain integration of large firms than on SMEs and that a complete transformation of SMEs from a myopic view to a collaborative and integrated approach is needed. A further example is that of Arend and Wisner (2005), who observed that the literature appears unresolved regarding the fit between SCI-SME.

Thus, and in agreement with the conclusions from the review of the literature on SCI conducted by Cousins et al. (2006), at present we are still dealing with an emerging management discipline, where a number of problems concerning the implementation of SCI in SMEs remain unsolved. One of these problems is that there are no methodologies adapted to the characteristics of SMEs that are capable of offering guidance to facilitate SCI while at the same time reducing the level of complexity (Humphreys et al. 2001).

On the one hand, there are the traditional reference architectures/methodologies for business integration (Bernus et al. 1996), including the CIM-OSA (Open Systems Architecture) Architecture presented in the ESPRIT programmes of the European Union (number 688, 2422 and 5288) by the AMICE Consortium (Amice 1993); the GIM (Grai Integrated Methodology) Architecture derived from the work carried out by several projects subsidised by the ESPRIT programme of the European Union, such as IMPACS (number 2338) by the GRAI Laboratory of Bordeaux University (France) (Doumeingts et al. 1992); and the PERA Architecture developed by Purdue University (USA) (Williams 1993). Nevertheless, these architectures were designed with the general internal integration of the enterprise in 
mind, and therefore do not take sufficiently into account the problems that exist within supply chains, especially as far as SMEs are concerned.

On the other hand, there are the methodologies that are specifically related to SCM, such as the Supply-Chain Operations Reference model (SCOR) (Supply Chain Council 2008); Collaborative Planning, Forecasting and Replenishment (CPFR) (Ireland and Crum 2005); or other methodologies that, despite not being created for this field of application, could also be useful, such as the Analytic Hierarchy Process (AHP) (Bhagwat and Sharma 2007a), Analytic Hierarchy Process-Pre-emptive Goal Programming (AHP-PGP) (Bhagwat and Sharma 2009) or Asset Management Tool (AMT) (Lin 2000). However, from the point of view of their applicability to SCI in SMEs, these methodologies present important shortcomings involving the actual parameters used to define the methodology; the high level of requirements as far as human, time or economic resources are concerned; the lack of vision for integrating the chain; or drawbacks due to problems in defining the Key Performance Indicators (KPIs) (Simatupang and Sridharan 2005).

Hence, there is still room for significant improvement in both the analysis and the theoretical study and practical definition of the methodology, as well as in the development of tools that are suitable for later application in the business world (Storey et al. 2006).

To help solve this problem, and following the premises that SCI implementation and maintenance in SMEs must be kept simple (Samaranayake 2002) and carried out with the smallest possible number of changes in the business processes of the organisation (Lamming et al. 2000), in this paper we propose a methodology that will enable SMEs to manage their supply chains in an integrated fashion. A case study of 30 SMEs will be used to produce a simple straightforward methodology that is adapted to the specific characteristics of SMEs and which will allow SMEs to overcome the barriers that prevent them from integrating their supply chains properly. The methodology is organised in different phases and makes it possible to: (1) Structure and plan SCI within an SME; (2) Analyse the environment surrounding the business and that of the actual supply chain; (3) Design a performance measurement system that, as pointed out by Leopoulos (2006) quoting Hudson, can give feedback regarding the quality of the decisions; (4) Analyse and redesign the main business processes, the activities carried out by human resources, and the computer support system; and (5) Implement the improvements and monitor the outcomes.

The paper is organised as follows: the next two sections present a review of the concept of SCI and an analysis of the current situation as regards the development and implementation of SCI in SMEs, to determine the main barriers preventing integration. Section four deals with the application of the case study research method carried out on 30 SMEs, and ends with the formulation of the methodology proposed for SCI and verification of the quality and scientific rigour of the research that was conducted. Section five outlines some considerations on the benefits observed by the SMEs that took part in the case study. Finally, section six offers the main conclusions from the research.

\section{Concept of Supply Chain Integration}

The concept of Supply Chain can be defined as "a set of three or more entities (organisations or individuals) directly involved in the upstream and downstream flows of products, services, finances, and/or information from a source to a customer" (Mentzer et al. 2001). Although the concept of Supply Chain is unanimously accepted in the management literature, the same cannot be said of the term SCM, although the insightful works by Gibson et al. (2005) and the one mentioned earlier by Mentzer et al. (2001) were a valuable aid when it came to obtaining a widely accepted definition of the term. 
In this regard, another interesting work is that by Stock and Boyer (2009), which identifies 173 different definitions of the term SCM that have been published in the literature since 1994, thus giving rise to a great deal of confusion among both academic as well as practitioner communities (New 1997; Tan 2001). These variations in the concept of SCM are to be expected to a certain extent because its traditional purchasing role has been replaced by a focus on outsourcing non-core activities and forming strategic alliances in a global context. The problem is that, as highlighted by Ross (1998), all too frequently the terminology used is excessively complicated, especially for the case of SMEs with simple organisational structures, and this greatly limits the extent to which they are understood and their effectiveness, above all when it comes to their practical application. Thus, for the purposes of this paper, it is more useful to identify the fundamental concepts that are common to the most widely accepted definitions, instead of using one particular definition of SCM. From this analysis it can be concluded that, in general, an adequate management of the supply chain must:

1. Choose the most appropriate form of organisation to be adopted in terms of integration and systematic and strategic coordination on a horizontal and/or vertical level, from the end user to the initial supplier who provides products, services and information with added value for customers and any other stakeholder (Mentzer et al. 2001).

2. Optimise the two-directional flow of goods, services, information, technology, human resources and knowledge among the components of the chain (Otto and Kotzab 2003).

3. Accomplish both common and specific goals with the aim of improving long-run performance, both for each business unit and for the chain as a whole (Lummus and Vokurka 1999). These aims will vary according to the area in which they are being contemplated. For instance, from the information technology and operations research perspective, the aim will be to minimise the cost of the flow of products given a particular level of service; from the point of view of the marketing area (Stock and Lambert 2001) the aim will be to satisfy the customer and to reduce the costs in the channel; or, from the system dynamics perspective (Stevens 1989), the goal will be to balance out demand and production, with the added problem of production and inventory management.

4. As pointed out by Tan et al. (1999, 2002), as well as Akkermans et al. (1999), implement a change in culture among the employees in the firms that make up the chain, the aim being to seek a more participatory style of management by introducing into their activities the concept of continuous improvement and the need to be customer-oriented.

From these common concepts it can be deduced that to achieve an adequate management of the supply chain it is necessary to accomplish the integration of the SC (Fawcett and Magnan 2002). Integration, as pointed out by the Council of Supply Chain Management Professionals (2005), allows the entire supply chain to be managed as a single process. In an integrated supply chain, all the functions that make up the supply chain are viewed as a single entity rather than separately as individual functions. The prevailing conventional wisdom in SCM literature is that the more integration is achieved, the better the performance of the supply chain will be (Christopher 1998; Harland et al. 1999; Lee 2000). The ideal situation, according to these authors, is for the entire process across the supply chain to be designed, managed and coordinated as a unit. Lee (2000) argued that a truly integrated supply chain did more than just reduce costs, since in fact it also created value for the company, its supply chain partners and its shareholders. In addition, Prahalad and Hamel (1994) and Hammer (2001) suggested that vertical integration should be replaced by virtual integration, where each participant concentrated on those processes that it performs best, leaving the rest to others. 
Both SMEs and LEs are seeking ways to integrate their supply chains. In this regard, Charlesworth et al. (2002) point out that SMEs are not only seeking ways to integrate the disparate systems within the organisation, but they have also moved to extend the integration beyond the boundaries of the organisation so as to include their suppliers, trading partners and customers. Integrating SMEs with their customers and trading partners will give these enterprises greater competitive advantage to compete with the larger companies or their competitors (Chen et al. 2004). Hence, as pointed out by Uden (2007), SCI is an important issue for SMEs and a critical component for enhancing SMEs' competitive advantage.

Several definitions have been proposed for SCI in the literature, without any common agreement being reached about its exact meaning (Lummus et al. 2008). In accordance with Bagchi and SkjoettLarsen (2005), in this paper we define SCI as a continuous process of improvement of the interactions and collaborations among supply chain network members to improve their ability to work together to reach mutually acceptable outcomes for their organisation.

This definition of SCI has been discussed in the context of SCM and we consider it for the objectives of the paper. However, there are also other approaches to SCI, such as Supply Chain Virtual Integration (SCVI). This involves using technology and information to blur the traditional boundaries among suppliers, manufacturers, distributors, and end users in a supply chain. SCVI is related to leveraging information on the supply chain to realise real-time asynchronous coordination of interfirm planning and execution in supply networks (Collin and Lorenzin 2006). SCVI, unlike traditional vertical "contractor-subcontractor" integration, represents the decomposition of the traditional company.

\section{Supply Chain Integration in SMEs. Benefits, Strengths, Threats and Obstacles}

As pointed out by Meehan and Muir (2008), both large and small enterprises identify SCI as a unique opportunity to obtain competitive advantage over their competitors. Nevertheless, the truth is that in practice SMEs do not include it in their management models and display weaknesses in connection with the conceptualisation, operationalisation and modelling of SCI (Ho et al. 2002). In a study conducted by Neuman and Samuels (1996), for example, it was found that only 5\% of SMEs could be considered to be actually working under what can be called SCI terms. The scant implementation of SCI in SMEs indicated by this figure was confirmed in another later study conducted by Quayle (2003), where it was shown that only 10\% of the SMEs that were analysed had a strategy for implementing SCI and had assigned a member of staff to be responsible for it.

Thakkar et al. (2008, 2009) and Arend and Wisner (2005) analysed the literature on supply chains in SMEs from the perspective of their integration and concluded that, given their different management models and resource capacities, the implementation must be undertaken from a different perspective depending on whether it is performed in SMEs or in LEs. The differences between SMEs and LEs go far beyond features such as the number of employees, turnover, and profit and loss statement included in their respective definitions.

Hence, as a first step towards fostering and facilitating a successful SCI in SMEs, it is essential to determine the main benefits that an SME can expect to observe, the SMEs' strong points that can smooth the process of supply chain integration, the threats they will have to cope with if they do not integrate their supply chains and the main obstacles that are hindering its implementation. 
With regard to the benefits, the management literature contains a number of works that identify the potential benefits that can derive from the integrated management of the supply chain in SMEs, some of the most notable being Fawcett et al. (2008), Meehan and Muir (2008), Chen et al. (2004) and Leopoulos et al. (2007). Table 1 shows the main potential benefits that were identified in these studies.

\section{Table 1. Main Potential Benefits of SCI}

As regards the strong points of SMEs, which can make their process of supply chain integration easier in relation to LEs, Gélinas and Bigras (2004) underline the following: (1) The extent of the owner-manager's involvement (direct contact with operations); (2) Focus on effectiveness rather than efficiency; (3) SME flexibility; (4) Simple decision-making process focused on immediate action; (5) The organisational structure of SMEs, which is conducive to internal and external interactivity; (6) Incremental, short-term planning; (7) Less precise division of responsibility, first because of the limited number of managers in SMEs, and second because the owner-manager often takes care of production management; (8) Swift market response time; and (9) Easy integration of suppliers and customers within continuous improvement teams.

On the other hand, Thakkar et al. (2009) and Meehan and Muir (2008) identify the threats presumably facing SMEs that do not integrate their supply chains: (1) Lack of a proactive attitude towards processes of change; (2) Possible shortcomings in the definition of their Mission, Vision, Goals and Strategies in their SCM; (3) Decreased competitiveness compared to competitors; (4) Possible lack of integration and definition in their organisational structure; (5) Absence of a suitable model for performance measurement; (6) Immature buyer-supplier relationships; (7) Lack of understanding on merits and demerits of alliances; (8) Non-optimised cycle times; and (9) Warehouse management problems.

Lastly, with respect to obstacles, Table 2 shows the ones that were identified from the extant literature and which have also been identified by the authors in implementing SCI in SMEs. To overcome such obstacles, an analysis is carried out to identify the specific characteristic of the SME that is causing them and a facilitator is proposed.

Table 2. Characteristics, Obstacles and Facilitators in SCI in SMEs

Following the model put forward by Meehan and Muir (2008), in the table obstacles have been arranged at three levels: Individual, Relational and Organisational.

- The individual level reflects obstacles corresponding to a lack of competencies (knowledge, capacities, skills, attitudes, training) on the part of those working in the supply chain.

- The relational level indicates the obstacles that refer to the relationships between the different components of the chain, as well as those that have to do with the actual structure of the organisation; in short, it expresses the role played by the SME itself in the supply chain. Another important obstacle is trust. If trust is present, it can improve the chances of a successful supply chain relationship; if not, transaction costs can rise through poor performance.

- The organisational level includes obstacles that have to do with management's involvement in and commitment to SCM, as well as with the decisions concerning the management and control of the supply chain. 
These obstacles show that SMEs face a significant risk of losing competitive power compared to LEs - a risk that can be summarised, as pointed out by Wagner et al. (2003), in the existence of an important gap between SMEs and LEs with regard to the state of the art of the tools and support systems for performing an effective SCI in SMEs. In short, as stated by Quayle (2003), the methodologies, and consequently the tools and techniques, that SMEs have available for a proper implementation of SCI have received very little attention to date.

Some of the benefits/obstacles are also benefits/obstacles of effective supply chain management (read as effective supply chain integration), as effective SCM is a result of effective supply chain integration.

\section{Methodological design of the case study}

After analysing the characteristics and obstacles that hinder correct integration of supply chains in SMEs, and given the fact that the literature does not contain any suitable methodologies to help with this integration, this paper describes a first approach to obtaining a methodology, called the SCI-IRIS methodology, which enables SMEs to integrate their supply chains.

The SCI-IRIS methodology was obtained by using the case study method. With regard to the validity of using the case methodology for this purpose, Larson and Halldorsson (2004) point out that: a current research need is to complement conceptual work and surveys on SCI with more longitudinal in-depth research of SCI in action, where case studies and interviews would provide the main sources of evidence.

The work plan that was followed consisted of seven stages and was based on the inductive analysis of qualitative data (Yin 1994), adapted to Walsham's (1995) proposals for generalisation of a theory from an interpretative investigation:

1. Definition of research purposes.

2. Definition of the conceptual context, perspectives. Literature review and proposals. Proposed theoretical model.

3. Identification of the units of analysis. Case selection.

4. Definition of research methods and resources.

5. Fieldwork. Data collection, triangulation and classification of information.

6. Formulation of the improved SCI-IRIS methodology.

7. Verification of the rigour and quality of the study.

We will now go on to describe the process included in each of these phases.

\subsection{Definition of research purposes}

The aim of this paper is to provide an answer to the question being asked in SMEs that are concerned about SCI, i.e. What methodology that has been designed to fit the characteristics of SMEs can help them to integrate their supply chains?

Unfortunately, today the answer to this question is that there are hardly any real practical methodological frameworks that can be used to allow organisations to integrate their supply chains.

Thus, the intended aim of this work is to provide the business world with a methodology that can help to carry out the implementation of SCI in SMEs in a structured manner. The methodology allows 
the internal integration of an SME. At the same time it makes it possible to integrate it with all the enterprises directly involved in the upstream and downstream of SME flows of products, services, finances, and/or information, such as suppliers, logistics service providers, distributors, retailers, and so forth.

\subsection{Definition of the conceptual context, perspectives. Literature review and proposals. Proposed theoretical model}

To successfully carry out a SCI in an SME, while at the same time reducing the degree of complexity, it would be a great aid to be able to use a stage-based methodology that defines the whole creative process in each phase. This would involve defining, among other things, the tasks to be performed, the techniques to be used, the modelling languages for representing the different domains and the technological infrastructure that allows the supply chain to be integrated.

With a view to solving this problem of a lack of such methodologies for SCI in SMEs, since 2005 the Integration and Re-engineering (IRIS) Group at the Universitat Jaume I in Castellón (Spain) has been working on a research project entitled "SCI-IRIS: Supply chain integration in SMEs". The aim was to develop and validate a methodology, called SCI-IRIS, that adopts a holistic vision to allow a supply chain within an SME to be optimised and integrated. Thirty SMEs from manufacturing sectors participated in the SCI-IRIS research project and were able to benefit from applying the methodology to their supply chains.

An initial version of the methodology was developed based on the literature review together with previous research and practical work on both enterprise integration and supply chain management in SMEs carried out by members of the IRIS group.

The results obtained by the IRIS group in business integration methodologies were very useful for defining the initial phases of the SCI-IRIS methodology. Thus, the findings accomplished in the integration of an enterprise (Chalmeta et al. 2001) and the integration of a network of enterprises that collaborate with one another (Chalmeta and Grangel 2003) made it possible to identify the need for the methodology to include among its different phases aspects such as the planning, the business analysis, the performance measurement or the business process re-engineering with its connection with human resources and the information system. Later, the experience of the IRIS group in real SCM work in SMEs was used to adapt these phases and to include others, such as supply chain analysis, in the methodology.

In addition, this initial version drew on ideas from other existing methodologies, like those that propose Benchmarking techniques to analyse the environment, those that apply Process re-engineering to achieve their integration, or the ones that help to define performance indicators, while always taking into account their adaptation to the specific characteristics of SMEs.

The initial version would then be applied to 30 industrial SMEs with the aim of improving it.

\subsection{Identification of the units of analysis. Case selection}

The research work was conducted over a period of 18 months. The first task was to select the organisations in which the case study was to be applied. First, contact was established by sending an email to 120 SMEs located in the Valencian Community (Spain), with which our research group had collaborated at some time in the past in different research and innovation projects. The email outlined the aims of the work, the expected benefits that they would gain from taking part in it and the 
workload that it would represent for the enterprise. After clearing up a number of doubts posed by the enterprises both by email and by phone, the number of SMEs was finally reduced to 55 . The criteria underlying the selection of this sample were essentially a willingness to collaborate in the research and the fact that the management of these enterprises were considering (or had at some time considered) improving the efficiency of their supply chain. This first group of 55 SMEs included enterprises belonging to different sectors.

Then, and in accordance with the different approaches to purposive sampling (Patton 1990), the criterion of selecting only industrial SMEs was adopted. Because this resulted in a more homogeneous sample, it was easier to arrange meetings, create templates for gathering data, and so forth, and would later simplify the process of analysing the findings. Nonetheless, within the industrial sector we sought the maximum level of variation among sub-sectors to explore whether the methodology could be useful for any type of industrial enterprise.

As a result of this second selection of companies, the decision was made to work with 30 SMEs that satisfied, in accordance with Yin (1994), all the requirements that were established in the design of this research. Table 3 shows some of the characteristics of the 30 SMEs participating in the study.

Table 3. Characteristics of the 30 participating SMEs.

The selected SMEs belonged to the following sectors of industrial activity: manufacture of ceramic tiles (10 SMEs), ancillary industry to the ceramic sector (5 SMEs), manufacture of furniture (5 SMEs), manufacture of textiles (5 SMEs) and the ancillary sector to the automotive industry (component manufacturers) (5 SMEs). Only the ceramic tile enterprises and some of the textile and furniture manufacturing enterprises dominate their supply chain. Moreover, the ancillary industry to the ceramic sector enterprises is the only one with a national supply chain. The other enterprises export part of their products and have international suppliers.

Most of the enterprises analysed, 20 altogether, belong to the segment of small enterprises, with the number of employees ranging from 0 to 50. The other 10 enterprises that were analysed are medium-sized companies with between 51 and 250 workers.

\subsection{Definition of research methods and resources}

After selecting the 30 SMEs, the fieldwork was prepared and begun. It must be noted that the characteristics of the different organisations were already known to the IRIS Research Group. The group was familiar with the way they were organised, their facilities, their products and services, their technological resources such as websites, and the group already had documentary evidence about them. This prior knowledge about the selected organisations allowed the research to get off on the best possible footing because it meant that important cuts could be made in the time spent on the tasks involving the gathering and analysis of information that have to be performed in any fieldwork.

In addition to the foregoing considerations, to begin the research work, a first meeting was held in each of the organisations. Each of these meetings lasted 90 minutes and they were attended by all, or nearly all, the department managers and middle management staff who it was thought could be related to the SCI in some way.

The meeting focused on the basic points of SCI and the methodology that was going to be used (initial version of the SCI-IRIS methodology). During the meeting emphasis was placed on the fact that 
the methodology was structured in phases that were adapted to fit the characteristics of the structure and the resources of SMEs as closely as possible.

Furthermore, to perform all the research tasks during the application of the methodology in each enterprise, mixed work teams were set up with members coming from both the IRIS Research Group and the SCI teams of each of the companies. These SCI teams were made up of either the people in charge of the supply chain activities (when such a department existed in the organisation) or members of staff who had taken part in the initial meeting, when SCM was either not implemented or did not correspond to a particular area. The purpose of the SCI teams was to be responsible for making decisions about all issues related to the work.

In general terms, efforts were made to ensure that the SCI teams consisted of full-time members of staff with some specific weight in the firm and who were familiar with the areas involved in the work. They were also organised in such a way that different components from each department participated in a sporadic but planned manner. Finally, in each organisation one person was appointed as being responsible for all the tasks related with the supply chain.

Later, a second meeting lasting 45 minutes was held with the organisations' SCI teams to plan the SCI and to begin to apply the initial version of the SCI-IRIS methodology. All the meetings were videotaped and later transcribed so that they could be analysed.

\subsection{Fieldwork. Data collection, triangulation and classification of information}

Once the aims of the research had been presented, data were then collected. This consisted in gathering the results of applying the initial version of the SCI-IRIS methodology in each of the SMEs. The results were collected following the different phases of the methodology using an assortment of questionnaires, templates and models, as well as copies of the documents and reports utilised in the enterprises. The data obtained refer to information about the planning; the situation in which the management of the supply chain currently finds itself, both externally, in relation to the other organisations in the sector, and internally, by searching for critical points in the management of the chain; the design and development of the SCI balanced scorecard; the description of the AS-IS and TO-BE supply chain processes and definition of the proposals for improvement; the creation of job handbooks that state who had to do what, how and with what resources; the requirements of the support information system and the evaluation of available technological solutions; the communication of the aims and the current status of the work; the identification of the benefits gained; and the comments and suggestions about the methodological procedure that was followed.

The next step was to structure and classify the different suggestions for improving the SCI-IRIS methodology for the SCI proposed by each of the mixed work groups as a result of their experience.

Following recommendations put forward by Yin (1998), multiple data sources and therefore compliance with the principle of triangulation were chosen to ensure the research could be replicated theoretically. This made it possible to verify whether the data obtained from applications to different companies were related to one another, that is to say, whether the effects explored were in line with the aim of the research when the initial version of the SCI-IRIS methodology was applied to the cases under analysis. In this case study, two triangulation types were considered: Spatial triangulation of data (three sources of data were considered: observation, interviews and documentation); Personal triangulation of data (all the people in charge of the supply chain activities from each enterprise were interviewed to obtain information from each of them). 


\subsection{Formulation of the improved SCI-IRIS methodology}

Once the improvements observed in each enterprise had been identified, different meetings were arranged with the representatives from all the companies to agree on the improvements that had been identified as necessary and implement them in the final SCI-IRIS methodology. It should be noted that agreements were reached relatively quickly.

The methodology that was finally obtained (SCI-IRIS) is divided into 9 phases:

I. SCI planning.

II. Analysis of the business.

III. Analysis of the Supply Chain.

IV. Designing the Balanced Scorecard of the Supply Chain.

V. Process redesign.

VI. Organisation and management of human resources.

VII. Construction of the information system.

VIII. Implementation.

IX. Continuous improvement.

These phases are not independent and must generally be implemented sequentially. The relation between the different phases can be seen in Figure 1. In addition, Table 4 shows a summary of the aims and techniques that were used in each phase of the methodology.

Figure 1. Diagram of the stages of the SCI-IRIS methodology

Table 4. Summary of the Activities, Aims and Techniques used in the SCI-IRIS Methodology

\section{PHASE I: SCI Planning}

In the first phase it is necessary to establish the scope of the SCI, specific aims and mechanisms of control. Thus, the first task to be performed is to specify what the SCI is to achieve by establishing a set of goals that are clear but attainable with the resources that are either already available or can be obtained.

The second task to be addressed is the commitment of management. To achieve this, it is necessary to get both Management and its steering committee totally involved so that they see the SCI as their own and are willing to act with conviction when possible deviations arise. To carry out this process of change successfully, there must be a proactive attitude towards it at the management level so that it is these same executives who transmit the virtues of the process of change within the different areas they are in charge of. To ensure that no area is left unaided, this will be the right time to review the different responsibilities within the organisational structure of the enterprise.

Once the commitment of management has been obtained, it is necessary to set up the work team, which will be directed by a coordinator chosen from among the persons with the greatest specific weight and experience inside the SME. This coordinator will answer directly to management and carry out tasks involving following up and coordinating the different work teams made up of skilled members of staff from each of the areas in the company. 
Lastly, in this first phase it is necessary to define the mechanisms that will be used to communicate the evolution of the SCI work. This will involve structuring what information is to be given to each level of the SME and how it is to get there, possible mechanisms being internal mail, informative meetings or bulletin boards.

During this phase it is necessary to create the plan for the SCI and to implement it in a project management software application, to establish the quality control mechanisms and to draw up the plan for change. The owners of the SME must allow its members to take part in the definition of the SCI work.

\section{PHASE II: Analysis of the Business}

The starting point within any management programme is always an analysis of the firm's objectives (mission, vision and strategy) and of its culture (policy and values). This is why it is essential, before beginning any SCI work, to understand and make the SME's strategy explicit by defining where the firm stands, where it wants to go and where it is actually going, as well as to analyse its culture, level of organisation and internal control.

To be able to carry out these tasks it is essential to have access to tools that, in the case of SMEs, must be of proven worth and simple to use. In the SCI-IRIS methodology, the model used to analyse the competitive environment of SMEs is the Five Forces model (Porter, 1980). On the other hand the model used to identify the influence of the Political, Economic, Social, Technological, Ecological and Legal factors on the environment surrounding SMEs in supply chain is the PESTEL model (Johnson and Scholes, 2002). This model allows a formalized appraisal of the context within which the supply chain operates and it is mainly useful in complex supply chain (Christopher and Peck, 2004). The practical application of a PESTEL model must be carried out through one or several brainstorming sessions attended by the components of the work team. At these meetings, which should not last more than 30 minutes, each of the members of the team will have to first generate new ideas about one of the influencing factors of the model. Then, the work team will have to evaluate all the ideas that have been put forward and choose the most representative ones.

The second task in this stage will be to redefine (or if it already exists, to make clear) the general strategy of the SME, which will state the way in which the processes are going to be carried out, as well as how the company's resources are going to be managed to reach the goals that have been set.

To define the business strategy, it is necessary to perform an in-depth analysis of the opportunities and threats that exist in the market, together with the strengths and weaknesses inherent to the organisation itself and all of this must be represented in a SWOT (Strengths, Weaknesses, Opportunities, and Threats) matrix. Elements such as market research, management of the firm's technical, human, economic and financial resources, planning and communication are essential to be able to carry out the business strategy properly. To define the SWOT matrix, it will be necessary to arrange a series of meetings similar to those held in the PESTEL analysis. The results of the analysis of the strengths and weaknesses performed using the SWOT matrix make it possible to identify the fundamental strategic goals that the SMEs have to be able to achieve their Mission and Vision. The analysis of their opportunities and threats enables us to identify the positive and negative aspects (respectively) of the sectoral environment that may or may not help them accomplish their Mission and Vision.

For the SME, clarifying its strategy correctly will have a positive effect on its future, as this will help to make up for the shortage of human and financial resources. 


\section{PHASE III: Analysis of the Supply Chain}

The purpose of this phase is to analyse the situation in which the SCM currently finds itself, both externally (in relation to the other firms in the sector) and internally, by searching for the critical points in the management of the chain within the organisation itself.

To do so, the analysis can be started by taking the Best Practices of leading SMEs in the sector as an example, while always bearing in mind the particularities of the different supply chains and their corresponding work environments.

Once the best practices that fit the particularities of the SME have been identified, it is advisable to reach an agreement with the other management staff in the organisation on complying with them, since this will provide an initial view of the situation of the organisation.

The next step will be to use the SWOT methodology, but restricting its scope of application to the supply chain to detect critical points in its management.

\section{- Analysis of the external environment of the supply chain:}

This analysis must focus on analysing the supply chain in the sectoral environment to search for possible business opportunities and threats (either existing or new) thanks to a novel utilisation of information technologies, the appearance of potential customers, changes in customers' habits, and so forth. These opportunities and threats can be detected by resorting to different sources of information, which may be private or public, in the form of reports from Chambers of Commerce, Universities or sectoral studies, and so on. Once the main strengths and weaknesses have been identified, the next step is to evaluate them to determine the extent to which they affect the supply chain.

\section{- Analysis of the internal environment of the supply chain:}

This analysis, unlike the previous one, will have to examine the supply chain from the SME's point of view, by analysing the strengths and weaknesses that exist in the whole internal work environment, but also by extending outwards so as to cover the relations with suppliers and customers. The aim is to perform a critical review of the performance of the processes and interactions among the components of the supply chain by posing a series of questions so that a process of reflection can be undertaken among all the members of the SME. This analysis will make it possible to establish a preliminary set of the main strong and weak points in the work procedures.

To finish this phase of the analysis of the supply chain, it will be necessary to identify and later classify the Critical Success Factors (CSF), which are the factors that the SME must focus on if it is to satisfy its suppliers' and customers' needs as effectively as possible. In sum, to identify them, the firm must ask itself questions like: What are the things, aspects, areas or activities in my supply chain that I cannot fail in because if I did, it would make it impossible to reach our goals and lead us away from fulfilling our Mission? The analysis of these factors will allow them to identify the actions with the highest priority among all the possible actions that can be included in the Action Plan. 


\section{PHASE IV: Designing the SCI Balanced Scorecard}

The aim of this phase is to design a balanced scorecard for managing the supply chain by identifying and classifying the KPIs that will make it possible to evaluate and control the objectives set for the supply chain and to do so in a structured and effective way (Hudson and Smith 2006).

Balanced Scorecards (BSCs) are traditionally structured on the grounds of the four classical perspectives defined by Kaplan and Norton (1996), but some authors such as Andersen et al. (2001) and Manville (2007) question the validity of their application for SMEs, pointing out that there is currently a gap in the literature regarding the implementation of BSC solutions in SMEs. Thus, the research conducted by Hudson et al. (2001a) and Turner (2005) concluded that SMEs can see the value of a performance measurement system but add that there are significant barriers to its implementation due to resource issues, the fact that it may be too strategically orientated and the difficulty involved in identifying KPIs.

In the initial version of the SCI-IRIS methodology the traditional four-perspective structure was followed. It was later found, however, that this approach was rejected by the different teams in the SMEs because they came up against many problems to define the strategic map when they tried to place the strategic goals into classical perspectives. In the end, and after analysing the different alternatives generated by the mixed work teams, the final version of the SCI-IRIS methodology proposes arranging the indicators in three new dimensions of work. This approach provided those in charge in each organisation with a simple way to identify the indicators that were best suited to the required level of management.

This phase is thus divided into three stages:

\section{Producing the Strategy Map}

As the basis for designing the Balanced Scorecard, first what is known as a Strategic Map must be produced and this requires a thorough analysis by management of all the goals that are to be reached, the relationships among them, and their time frame, with priority given to those goals that can help overcome the barriers that prevent SCI from being carried out. Moreover, continuous checks must be made to ensure the goals are actually in tune with the strategy.

\section{Determination of the Work Dimension of the Indicators}

This section proposes that, as a task to be carried out prior to identifying the indicators, the management of the firm should analyse the level the enterprise is to work at and whether it has the resources necessary to do so. To this end there are three possible Work dimensions of the indicators, which are alternatives that each company can combine to suit its own needs. These three Work dimensions of the indicators are as follows (see Figure 2):

Figure 2. Work dimensions of the indicators

\section{Management dimension}

This is the name given to the structuring of the indicators according to the decision level of the goals. It follows the classical model of management in organisations, i.e. strategic, tactical and operational. 


\section{Logistic process or area dimension}

At this level the indicators are classified according to the logistic process or area they are going to work in. This is perhaps the simplest classification when it comes to applying it in any enterprise. Management in the firm can detect the indicators in each case by going straight to the persons who work in the area in question every day and asking them for the information that is needed. These workers are thoroughly familiarised with the functioning and mechanisms available in their area and are therefore in a position to identify, define and quantify a suitable set of indicators.

The areas that are suggested in this dimension are as follows, although each SME must adapt them to meet its own particular characteristics: Supplier Service, Inventory Management, Warehousing, Production, Transport and Distribution, Customer Service and Reverse Logistics.

\section{Attribute dimension}

This third level involves classifying the indicators according to six attributes that can be organised in two different perspectives: from the external, or customer's, point of view and from the internal point of view. This last classification dimension is based on the SCOR methodology, but is extended by including the Efficiency attribute. The classification attributes are as follows:

\section{Customer perspective}

- Reliability. This measures the correct performance of the tasks in the supply chain.

- Responsiveness. This measures the speed at which the supply chain delivers products to its customers (whether internal or external).

- Flexibility. This measures the way the supply chain responds to changes in the market to gain or maintain its competitive advantage.

- Efficiency. This measures the rational use of the resources available to achieve a particular goal.

Internal perspective

- Cost. This measures the cost associated with the management of the supply chain itself.

- Management Assets. This measures the efficiency with which the organisation manages the assets that support the demand requirements.

\section{Identification of the Indicators}

Once we have defined the highest or lowest level of aggregation on which the enterprise wishes to work in each dimension, to follow up the goals set in the strategic map, the next step will be to identify suitable indicators for assessing and controlling those goals. Only indicators that measure the scope of the goals defined in the strategic map should be included, they must be expressed quantitatively and it must be easy for the organisation to understand their meaning.

One of the main advantages of structuring the indicators in different dimensions like this will prove to be very useful during the process of following up the goals, since it will have made it possible to assign the control of each of the indicators to the area that is best suited to doing so.

The last point in designing the BSC will be to produce, in each of the dimensions under consideration, a diagram of the causes and effects among the indicators so as to define the paths to be followed to achieve them. These cause-effect links will also serve as an effective diagnostic tool. 
PHASE V: Process Redesign

Once the organisational framework, the supply chain objectives and the indicators have been defined, the next step is similar to a business re-engineering. It involves redesigning the business processes of the company's supply chain to achieve the objectives that have been previously defined and to improve customer satisfaction and loyalty. It is important to point out that the aim is not for SMEs to study and computerise their current way of working, but to take advantage of the possibilities of the new information technologies to redesign and improve their processes involving the supply chain.

To build this new process map, it is necessary to (1) analyse the current situation (AS-IS model) by means of questionnaires and interviews with company staff, and (2) design what the company's supply chain processes should be like in the future, that is to say, the TO-BE model.

The limited resources that exist in SMEs make it necessary to determine the key internal and inter-organisational processes for the success of the SCI work, so as to be able to act upon them. Once they have been identified, the improvement process is carried out in four stages: process modelling, redesign, feasibility analysis and implementation of the improvement plan. The map of processes must include specification of the following aspects:

- Name and description of the process

- Type of process (support/customer)

- Inputs and Outputs

- Process diagram showing the sequence of activities

- Indicators for evaluating the process

- Critical Success Factors of the process

- Plan of improvements to the process

Some authors suggest that in redesigning business processes it is necessary to forget the AS-IS and to focus on the ideal operational model when it comes to designing the TO-BE. However, the IRIS group's experience in carrying out business process redesign and improvement at various enterprises shows that the existing means (human and technological resources, and so forth), as well as the company's culture and psychology, are a great restriction. Hence, when it comes to defining the business processes for the TO-BE, it is necessary to understand the AS-IS and choose the best realistic solution rather than suggesting ideal ones.

Developing business process models is a very useful way to understand the AS-IS and to represent improvements in the processes (the TO-BE). Different graphic representation techniques can be used to model AS-IS/TO-BE business processes (Chris, 1999). Our experience in real business process redesign projects (Chalmeta et al. 2001) leads us to conclude that one of the best solutions for modelling AS-IS/TO-BE business processes is IDEF0 (CAM-I, 1981). This is due to the fact that an IDEF0 model includes the most important aspects needed to understand the functioning of a process and the proposed improvements, but can nevertheless be understood by the members of staff at the enterprise who are not specialised in the use of models and have to use them and validate them. The weak point of IDEF0 is that it is static. Therefore, in complex processes in which the user is interested in simulating their behaviour over time (such as analysing bottlenecks, as would be the case in productive processes), the initial IDEF0 modelling can be completed with other modelling languages such as IDEF3, Petri Net, and so forth, which can be executed later on a computer. In our opinion, 
however, from a practical point of view it is more useful to model and simulate these processes with a commercial simulation software application.

A number of different tools can be used for identifying improvements in the SME's business processes. The most important are the knowledge and skill of the employees responsible for carrying out the redesign, the experience of the workers involved in the day-to-day execution of the process, the use of specialised consulting firms or comparison with other enterprises. For this last case it is very useful to have a reference model with best working practices. Models with practical improvements may be either general (that is, valid for any company) or sectoral. General models are not very detailed and, consequently, their use is rather limited in business process redesign. This is mainly because the reference models require a high level of detail and depth if they are to be useful in business process redesign. The reason for this is that all the activities in the process have to be identified, together with the inputs and outputs (information and materials), resources and controls. Thus, having access to a detailed sectoral model is very useful in such cases.

Furthermore, once the improvements to the process have been defined, they must be validated and they must be presented to the other components of the organisation. In this process, the tasks that have been defined in the new functional design must be shown to each of the areas involved. The aim of this is to seek the agreement and approval of the members of the organisation that are actually going to carry them out in their day-to-day commitments or, if necessary, to reconsider any issues that would not be feasible. Meetings shall continue to be held until all the aspects underlying the TO-BE model have been accepted by the organisation.

Finally, once the improvements have been validated to evaluate their cost-effectiveness and put them in order of priority (since resources are scarce - and more so in the case of SMEs), a feasibility analysis must be performed. Traditional cost/benefits analysis is a very useful tool to define the priority of the improvements. However, organisational, technical and operational aspects should also be considered.

\section{PHASE VI: Human Resources}

The people in a company are the key to any business strategy. This is the part that determines SCI success or failure and cannot be underestimated (Yee et al. 2008). Therefore, the aim of this phase is to ensure all members of the organisation are familiar with the SCI work, and to be able to allay their fears, concerns and doubts before it is implemented. They must understand the importance of SCI but, above all, they have to receive instruction on this new philosophy of integral management. The aim is to create a corporative culture in which its tasks are always approached taking into account the needs of suppliers and customers in each process.

This change in the corporative culture is not a single step in the SCI process and the main challenges involved are: to change the traditional culture focused on the individual short-term outcomes, which contradicts the vision of the SCI that seeks to achieve high performance and sustainable profitability in a way that benefits all contributors in the supply chain; to prevent decisions from being taken in isolation by weighing up the consequences in all the enterprises and departments involved; to bring about a change in the staff working in the organisation by pursuing a more participative style of management and by introducing the concept of continuous improvement into their activities; and to foster the creation of new and better relations among enterprises.

To overcome these challenges, both management and employees must understand and accept the strategic business value of the SCI. These key participants must realise that SCI is not just a 
technological strategy, but rather a business strategy that is essential to the success of the individual departments and the organisation as a whole. Only the commitment and support of both management and employees will make it possible to undertake the SCI and to share information efficiently throughout the entire supply chain.

The SCI will change the job roles and the organisational chart, since work teams will be set up with members of staff from different departments, such as Marketing, Warehousing, Production, Distribution, and so forth. This is a less hierarchical type of organisation (rather like process management) and this change must be set out in a handbook which contains descriptions of the different job profiles, the activities they must each perform, how they are to be done and with what resources.

Moreover, to manage this process of change, the Human Resources area will have to arrange awareness-raising and skill-development meetings. On the other hand, an integrated training plan for all levels of the organisation must be addressed, with the backing of management.

\section{PHASE VII: Information System}

To achieve real implementation of the SCI it is essential to have appropriate information and communication technology (ICT) that provides the information needed to coordinate, manage, operate and control the supply chain (Boone and Ganeshan 2007). In this phase of the SCI work, the SME will have to design that information and communications infrastructure. To do so, it will have to take the following aspects into account, among others:

- Definition of the hardware and software elements that will allow access to the technological infrastructure, and development of suitable converters.

- Establish a security system to ensure the quality, security and authenticity of the information about the users that access the infrastructure.

- Interoperability with the information systems of the different enterprises and organisations that belong to the supply chain.

- Integration of the computer system that automates the flows of information associated with the different business processes of the SME that are related to the supply chain.

- Development of a computer application to support the BSC that was defined in Phase III of the SCI-IRIS methodology.

Lastly, and once the importance of the information systems for the management of the supply chain has been acknowledged, firms must accept the fact that these systems are of no use whatsoever if the information that feeds them is not updated, if it is incorrect or if it does not flow quickly and accurately among the different links in the chain. It is thus essential that the area to be managed with the new information system should draw up a Training Plan, in coordination with Human Resources, for all the users of the new system.

\section{PHASE VIII: Implementation}

The next stage within the SCI-IRIS methodology concerns a Total Quality Plan and consists in implementing and controlling the migration from the old system (AS-IS) to the new one (TO-BE). Figure 3 shows an example of a template for managing the AS-IS/TO-BE analysis. The column entitled GAP + Restrictions shows the differences between the current way of working, the new proposal and the 
restrictions that exist for moving from the current to the future situation. Hence, the implementation plan can be broken down into a set of feasible proposals for improvement according to the financial and physical capacity of the enterprise.

Figure 3. Example of a template for the AS-IS/TO-BE analysis

Proposals for improvement can be arranged in order of priority, according to a viability study, and will make up the transition from AS-IS to TO-BE. Once they have been prioritised, the short-term proposals for improvement must be implemented. This will involve changing attitudes, both among management staff and among shop-floor workers, defining new work roles for each position, and redesigning the company's organisational chart. The outcome of this must be that everyone in the company has their duties assigned to them, as well as knowing what they must do and how to do it. Management of all the projected changes must be carried out by implementing control mechanisms similar to those used in the ISO-9000 Standard.

Adequate management of the change is essential in this section. It is common for the executives of an organisation to see that the organisation clearly needs to change, but they are unable to do so correctly because they invest a great deal of time and knowledge in developing the plan but very little time in how to get the organisation to implement, commit itself to and develop that change. To increase the chances of success, it is necessary to: (1) Develop a plan of communication which reflects the final vision of the SCI work and communicates it, and (2) Set up work teams that are responsible for the change and transmit it throughout the whole organisation by acting as catalysts. In this team, it is necessary to define exactly what its duties and responsibilities will be, who its members will be, what each of them will do, who its leader will be and how often meetings are to be held.

\section{PHASE IX: Continuous improvement}

Finally, it is necessary to construct a system of continuous improvement that allows: (1) the proposals for improvement that have been classed as medium and long term to be implemented in the future, while at the same time (2) adapting the company to the changes that may come about in its surroundings. When these proposals for improvement have been carried out, implementation of the SCI is complete.

While the SCI is being implemented, it is essential to define the monitoring, control and continuous improvement teams so as to be able to manage the deviations that are detected, to perform a follow-up of the indicators that were defined in the initial stage of managing the SCI, as well as to act appropriately to correct any deviations that may have arisen. Furthermore, these groups will act as catalysts in the presence of possible resistance to the process of supply chain integration.

\subsection{Verification of the rigour and quality of the study}

As a final step in the application of the case study to enhance the SCI-IRIS methodology, the results were analysed to check their validity and degree of confidence. To do so, the different models existing in the literature on management were reviewed and the model developed by Yin (1998) was finally chosen for use. This model is based on the verification of four tests to ensure the reliability and consistency of research based on case studies. These tests proposed by Yin are as follows: constructive, internal and external validity, and the reliability test. In carrying out this research, each of these tests was checked to ensure they were being fulfilled, since the works were carried out in strict 
compliance with the phases defined by the Proposed Methodological Design of the Case Study and by both theoretical and methodological triangulation, and triangulation of data. Moreover, systematic critical comparison was performed among the structured propositions from the theoretical reference model and those obtained from sources of evidence, to which replicating logic (multiple case studies) was applied to achieve analytical generalisation. The validity and quality of the study that was carried out can thus be confirmed.

\section{Significant benefits noted by participating SMEs}

One of the interesting aspects of the research work was to see how the application of the methodology in the 30 enterprises made it possible to overcome most of the barriers detected in the SMEs that prevented them from integrating their supply chains and obtaining some of the potential benefits listed in section 3 .

The benefits observed were identified four months after finishing the application of the SCI-IRIS methodology and, thus, the new organisational structures had been assimilated by the SMEs and the new management software had been implemented. To this end, a qualitative survey was prepared in which each of the people responsible for applying the SCI-IRIS methodology in the enterprise were given a questionnaire that included the 16 potential benefits shown in Table 1 . Three possible answers were offered for each of the benefits and they had to choose the one that best fitted their perception of the extent to which the benefit had been accomplished. The three options were the following: the benefit really had been accomplished, the benefit had not been obtained and an intermediate answer if it was not absolutely clear whether it had been achieved or not. A space was also provided in case an SME identified a new benefit, although none of them did so. The analysis of the results obtained in the questionnaires can be seen in Table 5, which shows the percentage of SMEs that said that a benefit really had been accomplished. No distinction was made between sub-sectors.

Table 5. Significant benefits observed by the SMEs

It is important to note that of the 16 potential benefits, four of them were identified as having really been accomplished by a very small number of enterprises. These potential benefits are: Lower the cost of labour, Cost of new product developments, Product innovation lead time and Increased access to financial support. One possible explanation for the low rate of accomplishment may be the fact that the SCI-IRIS methodology was only implemented a short time ago.

Other important results are the KPIs defined by the companies taking part in the project for each of the dimensions (Table 6 shows some of them). They can be used as a database of reference indicators organised according the SCI balanced scorecard. This could be a fundamental aid for defining the SCI indicators of a particular SME, since such enterprises do not possess any previous skills that enable them to identify and specify such indicators.

Table 6. Some KPIs identified in the case study

\section{Conclusions}

The literature review indicates that SCI is a competitive business approach for SMEs that, in practical terms, is not being carried out as often as expected. This is a consequence of a number of different factors, such as the absence of a methodology allowing SMEs to undertake all the tasks needed to reach SCI without neglecting their particular characteristics. 
To be able to carry out the integration of the supply chain within SMEs, the SCI-IRIS methodology was defined. To do so, an initial methodology was drawn up and applied to 30 SMEs, and later refined. The results obtained show that this step-by-step methodology enables SMEs to overcome the barriers that prevent them from achieving a correct integration of their supply chains and obtaining most of the significant benefits of SCI in SMEs reported in the literature.

Proposing a methodology like SCI-IRIS is an innovation in this field of research, since similar works based on case studies, such as the one by Chen et al. (2004), focus on analysing different aspects of SCI in SMEs, like benefits, degree of integration achieved, obstacles hindering its implementation, and so forth, but none of them propose a methodology.

Hence, the findings obtained are useful for the management staff of SMEs, since they can offer them some guidance on the potential benefits to be obtained from the integration of their supply chains. They may also provide solutions to a number of hidden organisational problems and which become apparent during the integration process. Another interesting conclusion from the application point of view is the structure proposed in the methodology for defining and assigning KPIs to the areas of responsibility that must work with them. Throughout this study this approach has proved to be wholly valid for the case of SMEs.

Within the academic field, the main contribution of this research lies in the fact that it has confirmed that the barriers preventing the integration of the supply chains in SMEs can be overcome if this integration is implemented by means of the SCI-IRIS methodology. Additionally, a solution to the problem of applying the BSC to SMEs described by authors such as Hudson et al. (2001b) has also been presented. This solution involves defining new dimensions of work for identifying and classifying KPIs.

Finally, it is important to discuss the limitations of the study and future prospects of the research. On the one hand, the limitations of this study are essentially concerned with the research method. Because it is a case study focused on a limited set of enterprises from the industrial sector, the validity of the methodology has not been proved in other sectors. Furthermore, the benefits to be gained by the enterprises from applying the methodology have not been measured objectively but are instead goals perceived by the managers. Although their experience leads us to suppose that they have been obtained, the method is not as exact as a quantitative analysis.

On the other hand, with regard to future prospects of the research, this work can be considered the starting point for future work that will complement the theoretical methodological approaches proposed here by refining some of the phases that have been outlined and by detecting SCI facilitators or new obstacles which will place new requirements on the methodology.

Hence, the methodology could be enriched by focusing on how to overcome the obstacles that have received the least attention, such as those related with the difficulties SMEs often have to gain access to ICTs, due to their high price and complexity, and especially the new Internet-based solutions, e-SCM. Likewise, it could also benefit from finding solutions to problems due to the (generally) insufficient investment in $\mathrm{R} \& \mathrm{D}$, which limits the introduction of continuous improvement processes in the supply chain.

Other future work should check the validity of the proposed methodology by applying it to other type of industrial SMEs like the chemical or machine tools industries and to other activity sectors. Perform statistical analyses to determine the difference between the benefits obtained in each sector could then be done. 
The last future work that is proposed is to adapt the methodology to the necessities of virtual supply chain integration, and to extend the methodology to allow the integration of all the supply chain, not only the integration of the SME with the enterprises directly involved in the upstream and downstream SME flows.

\section{ACKNOWLEDGEMENTS}

This work was funded by BANCAJA.

\section{References}

Akkermans, H., Bogerd, P. and Vos, B., 1999. Virtuous and vicious cycles on the road towards international supply chain management. International Journal of Operations \& Production Management, 19 (5/6), 565582.

Amice, C., 1993. CIM-OSA: Open System Architecture for CIM. Berlin: Springer-Verlag.

Andersen, H., Cobbold I. and Lawrie G., 2001. Balanced Scorecard implementation in SMEs: reflection on literature and practice. Paper presented to $4^{\text {th }}$ SME-SME International Conference. Allborg University, Denmark 14-16 May 2001.

Arend, R.J. and Wisner, J.D., 2005. Small business and supply chain management: is there a fit?. Journal of Business Venturing ,20, 403-436.

Bagchi, P.K. and Skjoett-Larsen, T., 2005. Supply Chain Integration: a European Survey. International Journal of Logistics Management, 16(2), 275-294.

Ballou, R.H., 2004. Business Logistics. Supply Chain Management. New Jersey: Prentice Hall.

Bernus, P., Nemes, L. and Williams, T.J., 1996. Architectures for Enterprise Integration. London: Chapman and Hall.

Bhagwat, R. and Sharma, M.K,. 2007a. Performance measurement of supply chain management using the analytical hierarchy process. Production Planning and Control, 18 (8), 666-680.

Bhagwat, R. and Sharma, M.K., 2007b. Information system architecture: a framework for a cluster of smalland medium-sized enterprises (SMEs). Production Planning and Control, 18(4), 283-296.

Bhagwat, R. and Sharma, M.K., 2009. An application of the integrated AHP-PGP model for performance measurement of supply chain Management. Production Planning and Control, 20 (8), 678-690.

Boone, T. and Ganeshan, R., 2007. The frontiers of eBusiness technology and supply chains. Journal of Operations Management, 25( 6) 1195-1198.

CAM-I: Consortium for Advanced Manufacturing - International, 1981. Architect's Manual, ICAM Definition Method, "IDEF0", ICAM Library Catalog, Poole (G.B), DR-80-ATCP-01.

Chalmeta, R., Campos, C. and Grangel, R., 2001. References architectures for enterprise integration. Journal of Systems and Software, 57 (3), 175-191.

Chalmeta, R. and Grangel, R., 2003. ARDIN extension for virtual enterprise integration. Journal of Systems and Software, 67, 141-152.

Chan, T.S., Qi, H.J., Chan, Henry C.W. and Ip, Ralph W.L., 2003. A conceptual model of performance measurement for supply chains. Management Decision, 41 (7), 635-642.

Charlesworth, I., Hamilton, J., Holden, M., Holt, E., Jagger, T., Jennings, T. and Jones, T., 2002. 'EAI and Web Services: Cutting the Cost of Enterprise Integration, in Technology.

Chen, H., Themistocleous, M. and Chiu, K.H., 2004. Approaches to Supply Chain Integration Followed By SMEs: An Exploratory Case Study. In: Proceedings of the Tenth Americas Conference on Information Systems, New York, 2610-2620.

Christopher, M., 1998. Logistics and Supply Chain Management. London: Pitman Publishing.

Collin, J., Lorenzin, D., 2006. Plan for supply chain agility at Nokia: Lessons from the mobile infrastructure industry. International Journal of Physical Distribution \& Logistics Management 36 (6), 418-430.

Council of Supply Chain Management Professionals, 2005. Terms and Glossary. http://www.cscmp.org/Downloads/Resources/glossary03.pdf. [Accessed March 5, 2010]. 
Cousins, P.D., Lawson, B. and Squire, B., 2006. Supply chain management: theory and practice. The emergence of an academic discipline?. International Journal of Operations \& Production Management, 26 (7), 697702.

Chris, M., 1999. Enterprise Modelling with UML: Designing Successful Software Through Business Analysis. Addison-Wesley, UK

Christopher M. and Peck H., 2004. Building the Resilient Supply Chain. International Journal of Logistics Management. 15 (2), 1-14.

Doumeingts, G., 1992. GRAI-GIM Integrated Methodology, A methodology for Designing CIM Systems, Version 1.0. LAP/ GRAI, University of Bordeaux, France.

European Comission, 2003 The new SME definition. User guide and model declaration. Extract of Article 2 of the Annex of Recommendation 2003/361/EC

Fawcett, S.E., Magnan, G.M. and McCarter, M.W., 2008. Benefits, barriers, and bridges to effective supply chain Management. Supply Chain Management: An International Journal, 13 (1), 35-48.

Fawcett, S.E., Magnan, G.M., 2002. The rhetoric and reality of supply chain integration. International Journal of Physical Distribution \& Logistics Management, 32 (5) 339 - 361

Forker, L.B., Mendez, D. and Hershauer, J.C., 1997. Total quality management in the supply chain: what is its impact on performance?. Intenational Journal of Production Research, 35 (6), 1681-1701.

Gélinas, R. and Bigras Y., 2004. The Characteristics and Features of SMEs: Favorable or Unfavorable to Logistics Integration?. Journal of Small Business Management 42(3), 263-278.

Gibson, B., Mentzer, J. and Cook, R., 2005. Supply Chain Management: Pursuit of a consensus definition. Journal of Business Logistics, 26 (2) $17-25$.

Giunipero, L., Handfield, R.B. and Eltantawy, R., 2006. Supply management's evolution: key skill sets for the supply manager of the future. International Journal of Operations\& Production Management, 26 (7) 822 844.

Gunasekaran, A., Patel, C. and Tirtiroglu, E., 2001. Performance measures and metrics in a supply chain environment. International Journal of Operations \& Production Management, 21(1/2), 71-87.

Hammer, M., 2001.The Agenda. What Every Business Must Do to Dominate the Decade. London: Random House Business Books.

Harland, C.M., Caldwell, N.D., Powell, P. and Zheng, J., 2007 Barriers to supply chain information integration: SMEs adrift of eLands. Journal of Operations Management, 25(6), 1199-1216.

Harland, C.M., Lamming, R.C. and Cousins, P.D., 1999. Developing the Concept of Supply Strategy, International Journal of Operations and Production Management 19(7), 650-673.

Ho, D.C.K., Au, K.F., and Newton, E., 2002. Empirical research on supply chain management: a critical review and recommendations. International Journal of Production Research, 40 (17), 4415-4430.

Hofmann, E. and Locker, A., 2009. Value-based performance measurement in supply chains: a case study from the packaging industry. Production Planning and Control, 20 (1), 68-81.

Hudson, M. and Smith, D., 2006. Implementing strategically aligned performance measurement in smalls firms. International Journal of Production Economics, 106 (2), 393-408.

Hudson, M., Lean, J., and Smart, P. A., 2001a. Improving control through effective performance measurement in SMEs. Production Planning and Control, 12 (8), 804-813.

Hudson, M., Smart, A. and Bourne, M., 2001b. Theory and practice in SME performance measurement Systems. International Journal of Operations \& Production Management, 21 (8), 1096-1115.

Humphreys, P.K., Lai M.K., and Sculli D., 2001. An Inter-organizational information system for supply chain management. International Journal of Production Economics, 70 (3), 245-255.

Ireland, R.K. and Crum, C., 2005. Supply Chain Collaboration: How to Implement CPFR and Other Best Collaborative Practices. Integrated Business Management Series. J. Ross Publishing, Inc.

Johnson, G. and Scholes, K., 2002. Exploring Corporate Strategy: Text and Cases. 6th edition, FT Prentice Hall, UK.

Kaplan, R.S. and Norton, D.P., 1996. Translating strategy into action - the Balanced Scorecard. Boston: Harvard Business School Press.

LaLonde, B.J., 2003. Three problems that linger. Supply Chain Management Review, 7 (2), 7-9.

Lamming, R., Johnsen, T., Zheng, J. and Harland, C., 2000. An initial classification of supply networks. International Journal of Operations and Production Management, 20(6), 675-691.

Larson, P. and Halldorsson, A., 2004. Logistics Versus Supply Chain Management: An International Survey. International Journal of Logistics: Research and Applications, 7 (1). 
Lee, H.L., 2000. Creating Value through Supply Chain Integration, Supply Chain Management Review 4(4), 3036.

Leopoulos, V., 2006. Editorial: Production and operations under SMEs' perspective. Production Planning and Control, 17 (3), 225 - 228.

Lewis, E., 2005. Now is SMEs' time to compete on-demand supply chain solutions are affordable for the small distributor. Industrial Distribution, September.

Lin, G., Ettl, M., Buckley, S., Bagchi, S., Yao, D., Naccarato, B., Allan, R., Kim, K., Koenig, L., 2000. Extended-Enterprise Supply Chain Management at IBM Personal System Group. Interfaces. 30, 34-38.

Leopoulos, V., Kirytopoulos, R. and Voulgaridou, D., 2007. SWOT analysis in supply chain clustering. Proceedings of the $11^{\text {th }}$ WSEAS International Conference on SYSTEMS. Agios Nikolaos, Crete, Greece, July 23-25.

Lummus, R.R. and Vokurka, R.J., 1999. Defining supply chain management: a historical perspective and practical guidelines. Industrial Management \& Data Systems, 99 (1), 11-17.

Lummus, R.R., Vokurka, R.J., Krumwiede, D., 2008. Supply Chain Integration and Organizational Success. Advanced Management Journal 73 (1), 11-17

Manville, G., 2007. Implementing a balanced scorecard framework in a not for profit SME. International Journal of Productivity and Performance Management, 56 (2), 162-169.

Meehan, J., and Muir, L., 2008. SCM in Merseyside SMEs: benefits and barriers. The TQM Journal, 20 (3), 223-232.

Mentzer, J.T., Dewitt, W., Keebler, J.S., Min, S., Nix, N.W., Smith, C.D. and Zacharia, Z.G., 2001. What is supply chain management?, in MENTZER J.T. (Ed) Supply chain Management, Thousand Oaks, CA, Sage Publications, 1-25.

Mentzer, J.T., Foggin, J.H. and Golicic, S.L., 2000. Collaboration: the enablers, impediments, and benefits. Supply Chain Management Review, 4 (4), 52-58.

Moberg, C.B., Speh, T.W. and Freese, T.L., 2003. SCM: making the vision a reality. Supply Chain Management Review, 7 (5), 34-40.

Monczka, R.M. and Morgan, J.P., 1997. What's wrong with supply chain management?. Purchasing, 122 (1), 69-73.

Morgan, J.P., 1997. Integrated supply chains: how to make them work!. Purchasing, 122 (8), 32-37.

Neuman, J. and Samuels, C., 1996. Supply chain integration: vision or reality?. Supply Chain Management: An International Journal, 1 (2), 7-10.

New, S.J., 1997. The scope of supply chain management research. Supply Chain Management: An International Journal t, 2 (1), 15-22.

Oakes, I. and Lee, G. 1999. Between a rock and a hard place: some dilemmas for smaller component suppliers, International Journal of Quality and Reliability Management, 16 (3), 252-262.

Otto, A. and Kotzab, H., 2003. Does supply chain management really pay? Six perspectives to measure the performance of managing a supply chain. European Journal of Operational Research. 144, 306-320.

Patton, M. Q., 1990. Qualitative evaluation and research methods (2nd ed.). Newbury Park, CA: Sage Publications.

Porter, M.E., 1980. Competitive Strategy: Techniques for Analyzing Industries and Competitors. Free Pr.

Prahalad C.K. and Hamel, G., 1994. Strategy As a Field of Study: Why Search for a New Paradigm, Strategic Management Journal, Special Issue 15, 5-16.

Power, D., 2006. Adoption of supply chain management-enabling technologies in SMEs: the view from the top vs. the view from the middle. International Journal of Value Chain Management, 1(1), 64-93.

Quayle, M., 2002. E-commerce: the challenge for UK SMEs in the twenty-first Century. International Journal of Operations and Productions Management, 22 (10), 1148-1161.

Quayle, M., 2003. A study of supply chain management practice in UK industrial SMEs. Supply Chain Management: An International Journal, 8 (1), 79-86.

Ritchie, B. and Brindley, C., 2000. Disintermediation, disintegration and risk in the SME global supply chain. Management Decision, 38 (8), 575-583.

Ross, D.F., 1998. Competing Through Supply Chain Management, New York, NY: Chapman \& Hall.

Samaranayake, P., 2002. Redesign of product and service delivery processes in BPR: an integrated approach. Paper presented at the $7^{\text {th }}$ International Conference on ISO 9000 and TQM, RMIT University, Melbourne.

Sastry, T., 1999. Supply chain strategies for small firms facing high demand uncertainty and seasonality. Vikalpa, 24 (4), 7-15. 
Sharma, M.K., Bhagwat and R. Dangayach, G.S., 2008. Performance measurement of information systems in small and medium sized enterprises: a strategic perspective. Production Planning \& Control, 19 (1), 12-24.

Simatupang, T.M. and Sridharan, R., 2005. Supply chain discontent. Business Process Management Journal. 11 (4), 349-369.

Singh, S., 1998. SME sector: current scenario and challenges. Small Enterprises Development, Management, Extension Journal, 25 (1), 4.

Skjoett-Larssen, T., 1999. Supply chain management: a new challenge for researchers and managers in logistics. International Journal of Logistics Management, 10 (2), 41-53.

Stevens, G.C., 1989. Integration of the supply chain. International Journal of Logistics Management. 19 (8), 38.

Stock, J.R. and Boyer, S.L., 2009. Developing a consensus definition of supply chain management: a qualitative study. International Journal of Physical Distribution \& Logistics Management, 39 (8), 690-711.

Stock, J.R. and Lambert, D.M., 2001. Strategic Logistics Management. 4th ed. Boston: Irwin/McGraw-Hill.

Storey, J., Emberson, C., Godsell, J. and Harrison, A., 2006. Supply chain management: theory, practice and future challenges. International Journal of Operations \& Production Management, 26 (7).

Supply Chain Council., 2008. SCOR, Supply-Chain Operations Reference Model.[online]. Available from: http://www.supply-chain.org [Accessed 31 March 2008].

Tan, E.N., Smith, G. and Saad, M., 2006. Managing the global supply chain: a SME perspective. Production Planning and Control, 17 (3), 238-246.

Tan, K.C., 2001 A framework of supply chain management literature. European Journal of Purchasing \& Supply Chain Management, 7, 39-48.

Tan, K.C., Handfield, R.B., Krause, D.R., 1998. Enhancing firm's performance through quality and supply base management: an empirical study. International Journal of Production Research, 36 (10), 2813-2837.

Tan, K.C., Kannan, V.R., Handfield, R.B. and Ghosh, S., 1999. Supply chain management: an empirical study of its impact on performance. International Journal of Operations \& Production Management, 19 (10), 1034-1052.

Tan, K.C., Lyman, S.B. and Wisner, J.D., 2002. Supply chain management: a strategic perspective. International Journal of Operations \& Production Management, 22 (5/6), 614-631.

Thakkar, J., Kanda, A. and Deshmukh, S.G., 2008. Supply chain Management in SMEs: development of constructs and propositions. Asia Pacific Journal of Marketing and Logistics, 20 (1), 97-131.

Thakkar, J., Kanda, A. and Deshmukh, S.G., 2009. Supply chain management for SMEs: a research introduction. Management Research News, 32 (10), 970-993.

Turner, T.J., Bititci, U.S. and Nudurupati, S.S., 2005. Implementation and impact of performance measures in two SMEs in Central Scotland. Production Planning and Control, 16 (2), 135-151.

Uden, L., 2007. How to Promote Competitive Advantage for SMEs: Issues, Ideas and Innovation. Journal of Business Systems, Governance and Ethics. 2 (2), 3.

Vaaland, T.I., Heide, M., 2007. Can the SME survive the supply chain challenges?. Supply Chain Management, $12(1), 20-31$.

Wagner, B.A, Fillis, I. and Johansson, U., 2003. E-business and e-supply strategy in small and medium sized businesses (SMEs). Supply Chain Management, 8 (4), 343-354.

Walsham, G., 1995. Interpretive case studies in IS research: nature and method. European Journal on Information Systems, 4, 74-81.

Williams, T., 1993. The Purdue Enterprise Reference Architecture. In: Proceedings of the Workshop on Design of Information Infrastructure Systems for Manufacturing. Tokyo: Elsevier Science.

Yee, R. Yeung, A. and Cheng, A.C., 2008. The impact of employee satisfaction on quality and profitability in high-contact service industries. Journal of Operations Management, 26 (5), 651-668.

Yin R.K., 1994. Case Study Research - Design and Methods, Applied Social Research Methods. 5, 2nd ed., Newbury Park, CA, Sage.

Yin R.K., 1998. The Abridged Version of Case Study Research. Bickman, L. and Rog, D J (eds.): Handbook of Applied Social Research Methods, Sage Publications, Thousand Oaks, 229-259. 
Table 1. Main Potential Benefits of SCI

\begin{tabular}{|c|c|}
\hline \multicolumn{2}{|c|}{ POTENTIAL BENEFITS IDENTIFIED } \\
\hline 1. Lower the cost of labour & 2. Cutting costs \\
\hline $\begin{array}{l}\text { 3. Integration of tasks and shared } \\
\text { information }\end{array}$ & $\begin{array}{l}\text { 4. Generate and identify new business } \\
\text { opportunities }\end{array}$ \\
\hline $\begin{array}{l}\text { 5. Collaboration and coordination } \\
\text { of all the components of the } \\
\text { supply chain }\end{array}$ & 6. Product innovation lead times \\
\hline $\begin{array}{l}\text { 7. Improvements in inventory } \\
\text { management }\end{array}$ & 8. Cost of new product development \\
\hline 9. Programming and follow-up & 10. Further performance improvements \\
\hline $\begin{array}{l}\text { 11. Significant improvements in both } \\
\text { customer and supplier services }\end{array}$ & $\begin{array}{l}\text { 12. Generation of a coordinated work } \\
\text { flow }\end{array}$ \\
\hline $\begin{array}{l}\text { 13. Sales, purchases, warehousing } \\
\text { and production departments can } \\
\text { share and process information } \\
\text { simultaneously }\end{array}$ & 14. Increased access to financial support \\
\hline $\begin{array}{l}\text { 15. Clear improvements in the } \\
\text { productivity of the operational } \\
\text { logistics system }\end{array}$ & $\begin{array}{l}\text { 16. Generation of proactivity with regard } \\
\text { to the process of SCI }\end{array}$ \\
\hline
\end{tabular}


Table 2. Characteristics, Obstacles and Facilitators in the implementation of SCI in SMEs

\begin{tabular}{|c|c|c|c|c|}
\hline LEVEL & $\begin{array}{c}\text { CHARACTERISTICS } \\
\text { OF SMES }\end{array}$ & OBSTACLES & AUTHORS & FACILITATORS \\
\hline \multirow{3}{*}{ 育 } & $\begin{array}{l}\text { Limited, non-optimised } \\
\text { resources }\end{array}$ & $\begin{array}{l}\text { (1).- Lack of expert staff to } \\
\text { manage the SCI. } \\
\text { (2).- Lack of suitable training. }\end{array}$ & $\begin{array}{l}\text { Meehan and Muir, } 2008 \\
\text { Fawcett et al. } 2008\end{array}$ & $\begin{array}{l}\text { Optimise and } \\
\text { prioritise existing } \\
\text { resources }\end{array}$ \\
\hline & $\begin{array}{l}\text { High turnover of skilled } \\
\text { employees }\end{array}$ & $\begin{array}{l}\text { (3).- Lack of experience in } \\
\text { managing improvement } \\
\text { programmes. } \\
\text { (4).- Lack of knowledge or } \\
\text { experience in e-solutions. }\end{array}$ & $\begin{array}{l}\text { Meehan and Muir, } 2008 \\
\text { Meehan and Muir, } 2008\end{array}$ & $\begin{array}{l}\text { Personal Career } \\
\text { Plan and Training }\end{array}$ \\
\hline & Resistance to change & $\begin{array}{l}\text { (5)- - Lack of interest in } \\
\text { participating in SCI. } \\
\text { (6)-- Doubts about the benefits to } \\
\text { be gained from changing } \\
\text { habits. }\end{array}$ & $\begin{array}{l}\text { Meehan and Muir, } 2008 \\
\text { Fawcett et al. } 2008\end{array}$ & $\begin{array}{l}\text { Motivation and } \\
\text { implication in the } \\
\text { organisational } \\
\text { change process }\end{array}$ \\
\hline \multirow{5}{*}{ 承 } & $\begin{array}{l}\text { Organisational structures } \\
\text { without formally defined } \\
\text { levels }\end{array}$ & $\begin{array}{l}\text { (7).- Existence of hidden and } \\
\text { unsolved inter-functional } \\
\text { conflicts. } \\
\text { (8)- Nobody responsible overall } \\
\text { for the whole supply chain. } \\
\text { (9).- Lack of trust among the } \\
\text { members of the supply chain. }\end{array}$ & $\begin{array}{l}\text { Fawcett et al., 2008. Mentzer et } \\
\text { al. 2000. Moberg et al. } 2003 . \\
\text { Monczka and Morgan, } 1997 . \\
\text { Meehan and Muir, 2008 } \\
\text { Meehan and Muir, } 2008\end{array}$ & $\begin{array}{l}\text { Formal definition } \\
\text { of the structure of } \\
\text { the organisation }\end{array}$ \\
\hline & $\begin{array}{l}\text { Management that is } \\
\text { usually personalised }\end{array}$ & $\begin{array}{l}\text { (10).- Lack of support and } \\
\text { commitment from } \\
\text { Management. } \\
\text { (11).- Lack of Guidelines from } \\
\text { Management. }\end{array}$ & $\begin{array}{l}\text { Moberg et al. 2003. Fawcett et } \\
\text { al., 2008. Monczka and } \\
\text { Morgan, 1997. } \\
\text { Mentzer et al. 2000., Morgan, } \\
1997\end{array}$ & $\begin{array}{l}\text { Management with } \\
\text { professional } \\
\text { support }\end{array}$ \\
\hline & $\begin{array}{l}\text { Informal and } \\
\text { undocumented definition } \\
\text { of the Vision and Strategy, } \\
\text { these being defined by the } \\
\text { owners of the organisation }\end{array}$ & (12).- $\quad$ Lack of SCI Vision. & $\begin{array}{l}\text { Moberg et al. } 2003 \text {. Mentzer et } \\
\text { al. 2000. Morgan, } 1997 . \\
\text { Thakkar et al. } 2009\end{array}$ & $\begin{array}{l}\text { Formal definition } \\
\text { of Mission, Vision, } \\
\text { Strategy and } \\
\text { Values }\end{array}$ \\
\hline & $\begin{array}{l}\text { Many members of the } \\
\text { organisation are unaware } \\
\text { of the Corporative Strategy }\end{array}$ & $\begin{array}{l}\text { (13).- Lack of Trust among the } \\
\text { members of the different } \\
\text { organisations when it comes } \\
\text { to considering SCI. }\end{array}$ & Fawcett et al. 2008 & $\begin{array}{l}\text { Make Strategy } \\
\text { known by levels }\end{array}$ \\
\hline & $\begin{array}{l}\text { Business in very limited } \\
\text { market segments and } \\
\text { based on the trust of a few } \\
\text { customers }\end{array}$ & $\begin{array}{l}\text { (14).- Lack of understanding of the } \\
\text { meaning of the concept of } \\
\text { SCI. }\end{array}$ & Moberg et al. 2003 & $\begin{array}{l}\text { Implication in the } \\
\text { SCM }\end{array}$ \\
\hline \multirow{3}{*}{ 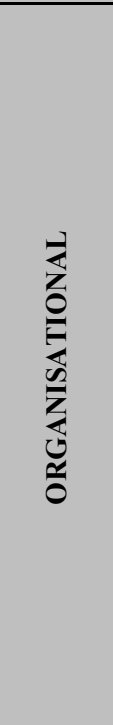 } & $\begin{array}{l}\text { Lack of integration } \\
\text { between some areas of } \\
\text { responsibility because their } \\
\text { duties are not fully } \\
\text { defined. It is not a priority } \\
\text { objective }\end{array}$ & $\begin{array}{l}\text { (15).- Lack of Trust among the } \\
\text { members of the organisation. } \\
\text { (16).- Little willingness to share } \\
\text { risks and rewards. } \\
\text { (17).- Lack of Integration between } \\
\text { the performance } \\
\text { measurement methods and } \\
\text { the practical requirements } \\
\text { necessary for SCI. } \\
\text { (18).- Fragmented approach and } \\
\text { lack of integration of SCI. } \\
\text { (19).- Difficulties in measuring } \\
\text { SCI. }\end{array}$ & $\begin{array}{l}\text { Mentzer et al. } 2000 \text {, } \\
\text { Moberg et al. } 2003 \\
\text { Fawcett et al. } 2008 \\
\text { Chan et al. } 2003 \\
\text { Thakkar et al. } 2009 \\
\text { Monczka and Morgan, } 1997 \\
\text { Monczka and Morgan, } 1997\end{array}$ & $\begin{array}{l}\text { Integration of tasks } \\
\text { and Methods }\end{array}$ \\
\hline & $\begin{array}{l}\text { Misalignment between } \\
\text { Business Strategy and } \\
\text { Processes }\end{array}$ & $\begin{array}{l}\text { (20).- Inflexibility of the } \\
\text { organisational system and } \\
\text { the processes. }\end{array}$ & Fawcett et al. 2008 & $\begin{array}{l}\text { Alignment of } \\
\text { Strategy and } \\
\text { Processes }\end{array}$ \\
\hline & $\begin{array}{l}\text { Increasingly more difficult } \\
\text { to obtain financial } \\
\text { resources }\end{array}$ & $\begin{array}{l}\text { (21).- Difficulties in gaining access } \\
\text { to specialised consultancies. } \\
\text { (22).- Price of expensive and } \\
\text { complex SCI computer } \\
\text { applications. }\end{array}$ & $\begin{array}{l}\text { Quayle, } 2003 \\
\text { Quayle, } 2003\end{array}$ & $\begin{array}{c}\text { To share costs with } \\
\text { other SMEs }\end{array}$ \\
\hline
\end{tabular}




\begin{tabular}{|c|c|c|c|}
\hline $\begin{array}{l}\text { Poor information } \\
\text { management }\end{array}$ & $\begin{array}{l}\text { (23).- Lack of resources devoted to } \\
\text { external communication, } \\
\text { while internal } \\
\text { communication is swift and } \\
\text { quite unstructured. } \\
\text { (24).- Unawareness of the potential } \\
\text { advantages of SCI. }\end{array}$ & $\begin{array}{l}\text { Fawcett et al. } 2008 \\
\text { Quayle, } 2003\end{array}$ & $\begin{array}{c}\text { Dedicate resources } \\
\text { to information } \\
\text { management }\end{array}$ \\
\hline $\begin{array}{l}\text { Widespread application of } \\
\text { non-integrated computer } \\
\text { management solutions }\end{array}$ & $\begin{array}{l}\text { (25).- Inadequate, Deficient or } \\
\text { Inexistent. IT/IS. }\end{array}$ & $\begin{array}{l}\text { LaLonde, } 2003 . \\
\text { Mentzer et al. } 2000 . \text { Monczka } \\
\text { and Morgan, } 1997 \\
\text { Sharma et al. } 2008 \\
\text { Thakkar } \text { et al. } 2009 \\
\text { Bhagwat y Sharma (2007b) }\end{array}$ & $\begin{array}{l}\text { Review and } \\
\text { integration of the } \\
\text { ICT systems }\end{array}$ \\
\hline $\begin{array}{l}\text { The implementation of } \\
\text { new technologies is not a } \\
\text { priority }\end{array}$ & $\begin{array}{l}\text { (26).- Insufficient development of } \\
\text { R\&D and Innovation } \\
\text { programmes. } \\
\text { (27).- They are not focused on the } \\
\text { implementation of EDI or } \\
\text { e-solutions in their } \\
\text { relationships with the } \\
\text { different components of the } \\
\text { chain. } \\
\text { (28).- Unawareness of application } \\
\text { methodologies. }\end{array}$ & $\begin{array}{l}\text { Vaaland, and Heide, } 2007 \\
\text { Vaaland and Heide, } 2007 \\
\text { Vaaland and Heide, } 2007\end{array}$ & $\begin{array}{c}\text { Prioritise } \\
\text { implementation of } \\
\text { new technologies }\end{array}$ \\
\hline $\begin{array}{l}\text { Scarce implementation of } \\
\text { a prior process to review } \\
\text { Strategy and data analysis }\end{array}$ & (29).- $\quad$ Badly planned SCI. & Morgan, 1997 & $\begin{array}{l}\text { Review of Goals } \\
\text { and Strategies }\end{array}$ \\
\hline $\begin{array}{l}\text { Lack of tools for } \\
\text { identifying, designing and } \\
\text { quantifying performance } \\
\text { indicators }\end{array}$ & $\begin{array}{l}\text { (30).- Lack of indicators for } \\
\text { measuring SCI. } \\
\text { (31).- Unawareness of the } \\
\text { methodology that is best } \\
\text { suited to their application. }\end{array}$ & $\begin{array}{l}\text { Mentzer et al. } 2000 \\
\text { Vaaland and Heide, } 2007\end{array}$ & $\begin{array}{l}\text { Define suitable } \\
\text { methodologies for } \\
\text { identifying } \\
\text { indicators }\end{array}$ \\
\hline $\begin{array}{l}\text { Relatively inexperienced } \\
\text { in the use of indicators for } \\
\text { business management }\end{array}$ & $\begin{array}{l}\text { (32).- } \text { Measurement of SCI } \\
\text { performance with } \\
\text { inconsistent and unsuitable } \\
\text { measures. } \\
\text { (33).- Confusion as regards the } \\
\text { number of indicators to be } \\
\text { defined and their assignation } \\
\text { to the corresponding area. } \\
\text { (34).- Imbalance between the } \\
\text { financial area indicators and } \\
\text { those of the other areas. }\end{array}$ & $\begin{array}{l}\text { Tan et al. 1998. Turner et al. } \\
2005 \text { Fawcett et al. } 2008 . \\
\text { Hofmann and Locker, } 2009 . \\
\text { Thakkar et al. 2009. } \\
\text { Gunasekaran et al. } 2001 \\
\text { Hudson et al. 2001a }\end{array}$ & $\begin{array}{l}\text { Define suitable } \\
\text { methodologies for } \\
\text { identifying } \\
\text { Indicators }\end{array}$ \\
\hline
\end{tabular}


Table 3. Characteristics of the 30 participating SMEs

\begin{tabular}{|c|c|c|c|c|c|c|c|c|c|}
\hline Organisation & Industrial activity & $\begin{array}{l}\text { No. of } \\
\text { employees }\end{array}$ & $\begin{array}{l}\text { Turnover } \\
\text { (Million } € \text { ) }\end{array}$ & $\begin{array}{l}\text { No. of } \\
\text { suppliers }\end{array}$ & No. of customers & $\begin{array}{l}\text { Position in } \\
\text { the SC* }\end{array}$ & $\begin{array}{l}\text { Logistics } \\
\text { Department }\end{array}$ & $\begin{array}{l}\text { Have the } \\
\text { CSF and } \\
\text { KPI been } \\
\text { defined? }\end{array}$ & $\begin{array}{l}\text { Certificates of } \\
\text { Quality }\end{array}$ \\
\hline 1 & Mfg. of ceramic tiles & 130 & 13,2 & 350 & 650 & $\mathrm{M}, \mathrm{D}$ & Yes, 6 people & No & ISO 9001 \\
\hline 2 & Mfg. of ceramic tiles & 150 & 15 & 270 & 430 & $\mathrm{M}$ & No & No & -- \\
\hline 3 & Mfg. of ceramic tiles & 45 & 18,5 & 20 & 850 & $\mathrm{D}$ & Yes, 6 people & $\begin{array}{l}\text { Yes, } \\
\text { partially }\end{array}$ & $\begin{array}{l}\text { ISO } 9001 \\
\text { ISO } 14001\end{array}$ \\
\hline 4 & Mfg. of ceramic tiles & 30 & 2 & 25 & 11 & $\mathrm{D}$ & No & No & -- \\
\hline 5 & Mfg. of ceramic tiles & 5 & 6 & 3 & 500 & $\mathrm{D}$ & No & No & ISO 9001 \\
\hline 6 & Mfg. of ceramic tiles & 160 & 13 & 240 & 400 & $\mathrm{M}$ & Yes, 4 people & $\begin{array}{l}\text { Yes, } \\
\text { partially }\end{array}$ & ISO 9001 \\
\hline 7 & Mfg. of ceramic tiles & 98 & 14,2 & 75 & 225 & $\mathrm{M}$ & Yes, 12 people & $\begin{array}{l}\text { Yes, } \\
\text { partially }\end{array}$ & $\begin{array}{l}\text { ISO } 9001 \\
\text { ISO } 14001\end{array}$ \\
\hline 8 & Mfg. of ceramic tiles & 66 & 12,3 & 150 & 250 & $\mathrm{M}, \mathrm{D}$ & Yes, 3 people & No & -- \\
\hline 9 & Mfg. of ceramic tiles & 39 & 6,7 & $>100$ & $>300$ & $\mathrm{M}$ & No & No & -- \\
\hline 10 & Mfg. of ceramic tiles & 35 & 8,7 & 250 & 400 & $\mathrm{M}$ & No & No & -- \\
\hline 11 & $\begin{array}{l}\text { Ancillary industry to } \\
\text { the ceramic sector }\end{array}$ & 18 & 12,2 & 35 & 15 & $\mathrm{M}, \mathrm{D}$ & Yes, 3 people & No & $\begin{array}{l}\text { ISO } 9001 \\
\text { ISO } 14001 \\
\end{array}$ \\
\hline 12 & $\begin{array}{l}\text { Ancillary industry to } \\
\text { the ceramic sector }\end{array}$ & 32 & 13,5 & 35 & 20 & M, D & Yes, 4 people & No & $\begin{array}{l}\text { ISO } 9001 \\
\text { ISO } 14001\end{array}$ \\
\hline 13 & $\begin{array}{l}\text { Ancillary industry to } \\
\text { the ceramic sector }\end{array}$ & 22 & 1,8 & 20 & 38 & $\mathrm{M}$ & No & No & -- \\
\hline 14 & $\begin{array}{l}\text { Ancillary industry to } \\
\text { the ceramic sector }\end{array}$ & 12 & 2 & 18 & 34 & $\mathrm{M}$ & No & No & -- \\
\hline 15 & $\begin{array}{l}\text { Ancillary industry to } \\
\text { the ceramic sector }\end{array}$ & 17 & 3,4 & 20 & 43 & $\mathrm{M}$ & No & No & -- \\
\hline 16 & Mfg. of furniture & 49 & 3,34 & 30 & 200 & $\mathrm{M}$ & No & No & -- \\
\hline 17 & Mfg. of furniture & 50 & 6 & 100 & 35 & M & Yes, 4 people & No & $\begin{array}{l}\text { ISO } 9001 \\
\text { ISO } 14001 \\
\end{array}$ \\
\hline 18 & Mfg. of furniture & 37 & 3,2 & 46 & 38 & $\mathrm{M}$ & No & No & -- \\
\hline 19 & Mfg. of furniture & 87 & 8,3 & 78 & 27 & $\mathrm{M}$ & Yes, 4 people & $\begin{array}{l}\text { Yes, } \\
\text { partially }\end{array}$ & $\begin{array}{l}\text { ISO } 9001 \\
\text { ISO } 14001\end{array}$ \\
\hline 20 & Mfg. of furniture & 54 & 5,7 & 44 & 57 & $\mathrm{M}$ & No & No & -- \\
\hline 21 & Mfg. of textiles & 36 & 2,3 & 30 & 46 & $\mathrm{M}$ & No & No & -- \\
\hline 22 & Mfg. of textiles & 42 & 2,7 & 32 & 42 & $\mathrm{M}$ & No & No & -- \\
\hline 23 & Mfg. of textiles & 53 & 3,1 & 32 & 53 & $\mathrm{M}$ & Yes, 2 people & No & ISO 9001 \\
\hline 24 & Mfg. of textiles & 50 & 3,4 & 28 & 48 & $\mathrm{M}$ & Yes, 5 people & $\begin{array}{l}\text { Yes, } \\
\text { partially }\end{array}$ & ISO 9001 \\
\hline 25 & Mfg. of textiles & 38 & 2,8 & 26 & 46 & $\mathrm{M}$ & No & No & -- \\
\hline 26 & $\begin{array}{l}\text { Ancillary sector to } \\
\text { the automotive } \\
\text { industry } \\
\text { (components) } \\
\end{array}$ & 63 & 8,4 & 32 & 6 & $\mathrm{M}$ & Yes, 8 people & $\begin{array}{l}\text { Yes, } \\
\text { partially }\end{array}$ & $\begin{array}{l}\text { ISO } 9001 \\
\text { ISO } 14001\end{array}$ \\
\hline 27 & $\begin{array}{l}\text { Ancillary sector to } \\
\text { the automotive } \\
\text { industry } \\
\text { (components) }\end{array}$ & 60 & 8 & 38 & 8 & $\mathrm{M}$ & Yes, 6 people & $\begin{array}{l}\text { Yes, } \\
\text { partially }\end{array}$ & $\begin{array}{l}\text { ISO } 9001 \\
\text { ISO } 14001 \\
\text { OHSAS } 18001\end{array}$ \\
\hline 28 & $\begin{array}{l}\text { Ancillary sector to } \\
\text { the automotive } \\
\text { industry } \\
\text { (components) }\end{array}$ & 32 & 6,7 & 25 & 6 & $\mathrm{M}$ & Yes, 3 people & $\begin{array}{l}\text { Yes, } \\
\text { partially }\end{array}$ & $\begin{array}{l}\text { ISO } 9001 \\
\text { ISO } 14001\end{array}$ \\
\hline 29 & $\begin{array}{l}\text { Ancillary sector to } \\
\text { the automotive } \\
\text { industry } \\
\text { (components) }\end{array}$ & 43 & 6,9 & 43 & 9 & $\mathrm{M}$ & Yes, 4 people & $\begin{array}{l}\text { Yes, } \\
\text { partially }\end{array}$ & $\begin{array}{l}\text { ISO } 9001 \\
\text { ISO } 14001\end{array}$ \\
\hline 30 & $\begin{array}{l}\text { Ancillary sector to } \\
\text { the automotive } \\
\text { industry } \\
\text { (components) }\end{array}$ & 40 & 9 & 27 & 6 & $\mathrm{M}$ & Yes, 7 people & $\begin{array}{l}\text { Yes, } \\
\text { partially }\end{array}$ & $\begin{array}{l}\text { ISO } 9001 \\
\text { ISO } 14001 \\
\text { OHSAS } 18001\end{array}$ \\
\hline
\end{tabular}


2

3

4

5

6

7

8

9

Figure 1. Diagram of the stages of the SCI-IRIS Methodology

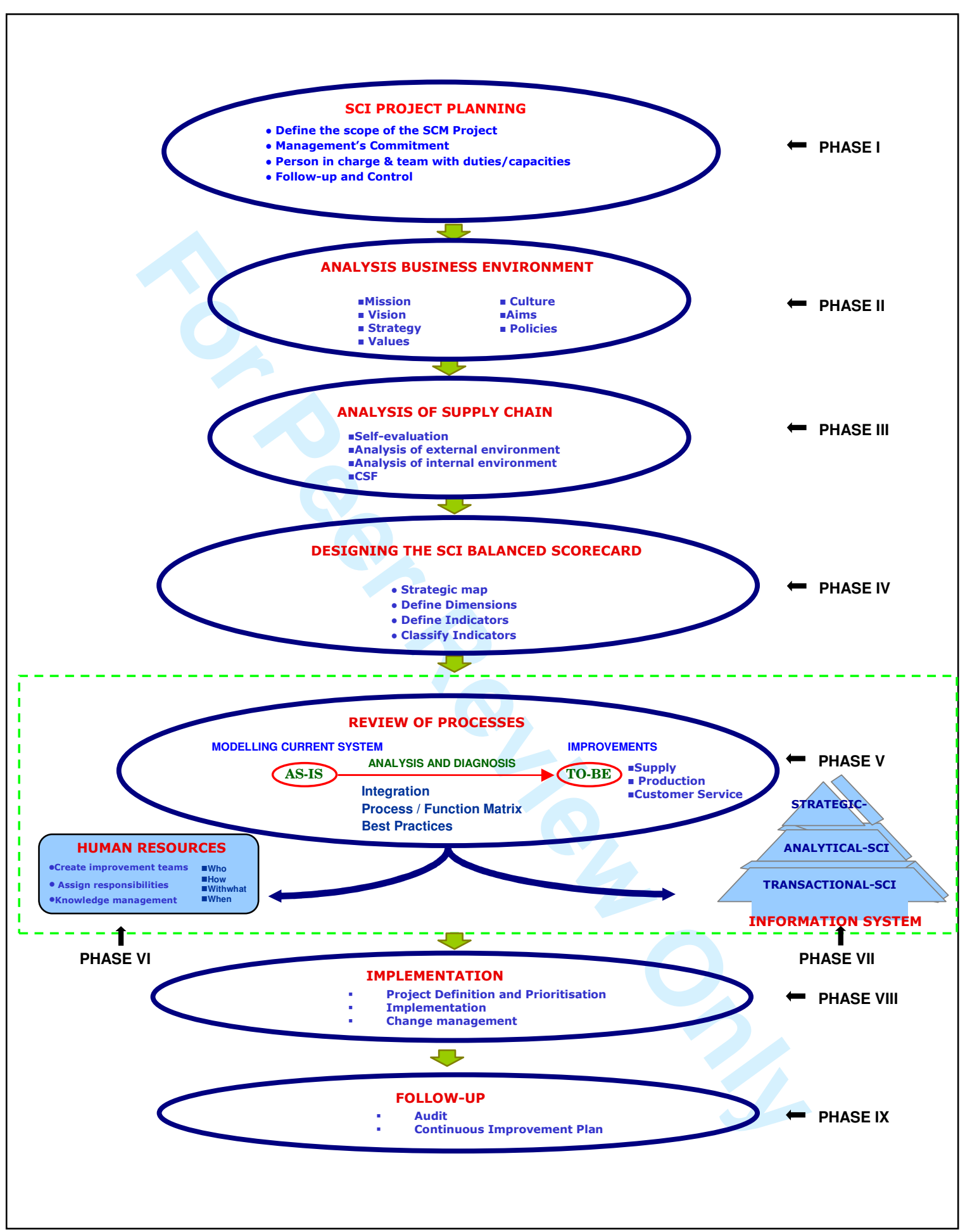


Table 4. Summary of the Activities, Aims and Techniques used in the SCI-IRIS Methodology

\begin{tabular}{|c|c|c|c|}
\hline PHASE & ACTIVITY & OBJECTIVES & TECHNIQUES / TOOLS \\
\hline \multirow[t]{4}{*}{ I. SCI PLANNING } & Definition of the goals of the $\mathrm{SCl}$ & Commitment by Management & $\begin{array}{l}\text { Presentation Meeting with } \\
\text { Management }\end{array}$ \\
\hline & Definition of Resources & Allocation of resources to the $\mathrm{SCl}$ & Loads /Availability \\
\hline & Organisation of $\mathrm{SCl}$ & Define those in charge and teams & Project Management Software \\
\hline & $\begin{array}{l}\text { Definition of Communication, } \\
\text { Monitoring and Control } \\
\text { Mechanisms }\end{array}$ & $\begin{array}{l}\text { Involvement of the organisation members in the } \\
\mathrm{SCl}\end{array}$ & $\begin{array}{l}\text { Periodic meetings, Notice boards, } \\
\text { etc. }\end{array}$ \\
\hline \multirow{3}{*}{$\begin{array}{l}\text { II. ANALYSIS OF THE } \\
\text { BUSINESS } \\
\text { ENVIRONMENT }\end{array}$} & $\begin{array}{l}\text { Definition of Business goals and } \\
\text { Culture }\end{array}$ & $\begin{array}{l}\text { Formal definition of: Mission, Vision, Values and } \\
\text { Strategies }\end{array}$ & Management Meetings \\
\hline & \multirow[t]{2}{*}{$\begin{array}{l}\text { Analysis of the SME } \\
\text { Environment }\end{array}$} & SME Sectoral Analysis & $\begin{array}{l}\text { PESTEL Model } \\
\text { Five Forces Model (Porter) }\end{array}$ \\
\hline & & Positioning of SME & $\begin{array}{l}\text { SWOT Matrix (Applied at the sectoral } \\
\text { level) }\end{array}$ \\
\hline \multirow[t]{4}{*}{$\begin{array}{l}\text { III. ANALYSIS OF THE } \\
\text { SUPPLY CHAIN }\end{array}$} & Self-evaluation of the SCM & Verify the situation of the SC & $\begin{array}{l}\text { Internal Questionnaire SC } \\
\text { Identification of Best Practices }\end{array}$ \\
\hline & $\begin{array}{l}\text { Analysis of the External } \\
\text { environment of the SC }\end{array}$ & $\begin{array}{l}\text { Opportunities and Threats } \\
\text { Implications } \\
\text { Possible Actions taken }\end{array}$ & $\begin{array}{l}\text { Benchmarking } \\
\text { SWOT Matrix }\end{array}$ \\
\hline & $\begin{array}{l}\text { Analysis of the Internal } \\
\text { environment of the SC }\end{array}$ & $\begin{array}{l}\text { Strengths and Weaknesses } \\
\text { Implications } \\
\text { Possible Actions taken }\end{array}$ & SWOT Matrix \\
\hline & Critical Success Factors (CSF) & $\begin{array}{l}\text { Identification of CSF } \\
\text { Classification and Prioritisation of CSF }\end{array}$ & $\begin{array}{l}\text { CSF Template } \\
\text { Decision and Prioritisation Matrices }\end{array}$ \\
\hline \multirow[t]{7}{*}{$\begin{array}{l}\text { IV. DESIGNING THE SCI } \\
\text { BALANCED } \\
\text { SCORECARD }\end{array}$} & $\begin{array}{l}\text { Determination of the Work } \\
\text { dimension of the indicators: } \\
\text { - Management Dimension } \\
\text { - Logistic Process/Area } \\
\text { Dimension } \\
\text { - Attribute Dimension }\end{array}$ & $\begin{array}{l}\text { Selection of the work dimension from the } \\
\text { indicators according to the organisation's needs }\end{array}$ & \multirow[t]{5}{*}{ SCI Balanced Scorecard } \\
\hline & Production of the Strategic Map & Locate and relate CSF & \\
\hline & Identification of the KPIs & $\begin{array}{l}\text { Identification according to the dimension that is } \\
\text { sought }\end{array}$ & \\
\hline & Formulation of the KPIs & Specification of each Indicator & \\
\hline & $\begin{array}{l}\text { Classification of the Indicators } \\
\text { by Dimension }\end{array}$ & Locate KPIs & \\
\hline & $\begin{array}{l}\text { Follow-up of the Cause-and- } \\
\text { Effect Strategic Map }\end{array}$ & Correct deviations & Follow-up meetings \\
\hline & Definition of Goals & Levels of performance & Evaluation meetings \\
\hline \multirow[t]{6}{*}{$\begin{array}{l}\text { V. REVIEW OF } \\
\text { PROCESSES }\end{array}$} & $\begin{array}{l}\text { Internal and inter- } \\
\text { organisational process } \\
\text { modelling }\end{array}$ & $\begin{array}{l}\text { Description of Work Processes (AS-IS): } \\
\text {-Tasks } \\
\text {-Resources (Human and Technical) } \\
\text {-Relations }\end{array}$ & $\begin{array}{l}\text { - IDEFO Modelling (what) } \\
\text { - RAD (Role Activity Diagram) (who, } \\
\text { where) }\end{array}$ \\
\hline & $\begin{array}{l}\text { Integrate Internal and inter- } \\
\text { organisational processes } \\
\end{array}$ & Process map (AS-IS) & Processes / Functions Matrix \\
\hline & \multirow{4}{*}{$\begin{array}{l}\text { Diagnosis and Proposal for } \\
\text { Improvements }\end{array}$} & Verify initial situation & $\begin{array}{l}\text { Positioning Study } \\
\text { Self-diagnosis by EFQM Modelling }\end{array}$ \\
\hline & & Review and analysis of existing processes & $\begin{array}{l}\text { Benchmarking } \\
\text { Best Practices (external) } \\
\text { Own Practices (internal) } \\
\end{array}$ \\
\hline & & $\begin{array}{l}\text { Process Map (TO-BE) } \\
\text { Contingency Diagram (actions/people } \\
\text { responsible) }\end{array}$ & $\begin{array}{l}\text { - IDEFO Modelling (what) } \\
\text { - RAD (Role Activity Diagram) (who, } \\
\text { where) }\end{array}$ \\
\hline & & Management of identified misalignments & GAP Analysis meetings \\
\hline \multirow[t]{4}{*}{ VI. HUMAN RESOURCES } & Change Management & $\begin{array}{l}\text { Training: Cohesion process, Skills development } \\
\text { plan }\end{array}$ & $\begin{array}{l}\text { Awareness-raising meetings } \\
\text { Training courses }\end{array}$ \\
\hline & $\begin{array}{l}\text { Define jobs, tasks and } \\
\text { responsibilities (who, what, } \\
\text { where and how) }\end{array}$ & Production of Job Handbooks & Templates for defining jobs \\
\hline & $\begin{array}{l}\text { Creation of teams for improving } \\
\text { the } \mathrm{SCl}\end{array}$ & $\begin{array}{l}\text { Definition of members and responsibilities } \\
\text { Implementation of improvements }\end{array}$ & $\begin{array}{l}\text { Assignation meetings } \\
6 \text { Sigma methodology }\end{array}$ \\
\hline & $\begin{array}{l}\text { Creation of the programme of } \\
\text { training schemes }\end{array}$ & $\begin{array}{l}\text { Training of management } \\
\text { Training of shop-floor workers } \\
\text { Training of different teams }\end{array}$ & Training Courses \\
\hline \multirow[t]{3}{*}{$\begin{array}{l}\text { VII. INFORMATION } \\
\text { SYSTEMS }\end{array}$} & Design of Information System & $\begin{array}{l}\text { Define requirements catalogue: } \\
\text { General, technical and functional specifications }\end{array}$ & \multirow{3}{*}{$\begin{array}{l}\text { Software development models } \\
\text { Methodology for computer software } \\
\text { development }\end{array}$} \\
\hline & $\begin{array}{l}\text { Allocation of Human and } \\
\text { Technical Resources }\end{array}$ & Define Development Teams & \\
\hline & Design the system architecture & $\begin{array}{l}\text { - Analysis } \\
\text { - Design } \\
\text { - Programming }\end{array}$ & \\
\hline
\end{tabular}




\begin{tabular}{|c|c|c|c|}
\hline PHASE & ACTIVITY & OBJECTIVES & TECHNIQUES / TOOLS \\
\hline & $\begin{array}{l}\text { Plan for testing the interface } \\
\text { with the previous IS }\end{array}$ & Definition of Prototypes & \\
\hline & $\begin{array}{l}\text { Utilisation Control and } \\
\text { Management }\end{array}$ & $\begin{array}{l}\text { Define procedures to control access, operation } \\
\text { and administration of the system }\end{array}$ & \\
\hline & IS Training Schemes & Training of Users & Training Courses \\
\hline \multirow[t]{5}{*}{ VIII. IMPLEMENTATION } & \multirow[t]{2}{*}{ Total Quality Plan } & Quality Assurance and Control & $\begin{array}{l}\text { ISO } 9000 \\
\text { Communication Plan }\end{array}$ \\
\hline & & Training of implementation teams & \\
\hline & $\begin{array}{l}\text { Compare the present and } \\
\text { future situations }\end{array}$ & $\begin{array}{l}\text { Identify restraints and proposals for } \\
\text { improvement }\end{array}$ & AS-IS, TO-BE, GAPS templates \\
\hline & \multirow[t]{2}{*}{ Migration Plan } & Planning and responsibilities & Project Management Software \\
\hline & & $\begin{array}{l}\text { - Feasibility study } \\
\text { - Prioritise proposals for improvement }\end{array}$ & Cost/efficiency approach models \\
\hline \multirow[t]{3}{*}{$\begin{array}{l}\text { IX. CONTINUOUS } \\
\text { IMPROVEMENT }\end{array}$} & $\begin{array}{l}\text { Monitoring the } \\
\text { implementation. Control and } \\
\text { improvement teams }\end{array}$ & $\begin{array}{l}\text { Control of deviations over time } \\
\text { Prevent resistance to change/motivation } \\
\text { Measure the degree of participation } \\
\text { Evaluation of results } \\
\text { Monitoring indicators }\end{array}$ & Follow-up and control meetings \\
\hline & Quality assurance & Meet ISO 9000 requirements & ISO 9000 Model \\
\hline & Continuous improvement & $\begin{array}{l}\text { Periodic review } \\
\text { Management of improvements that are } \\
\text { identified }\end{array}$ & $\begin{array}{l}\text { Continuous Improvement meetings } \\
\text { Application of Continuous } \\
\text { Improvement Techniques }\end{array}$ \\
\hline
\end{tabular}


Figure 2. Work dimensions of the indicators

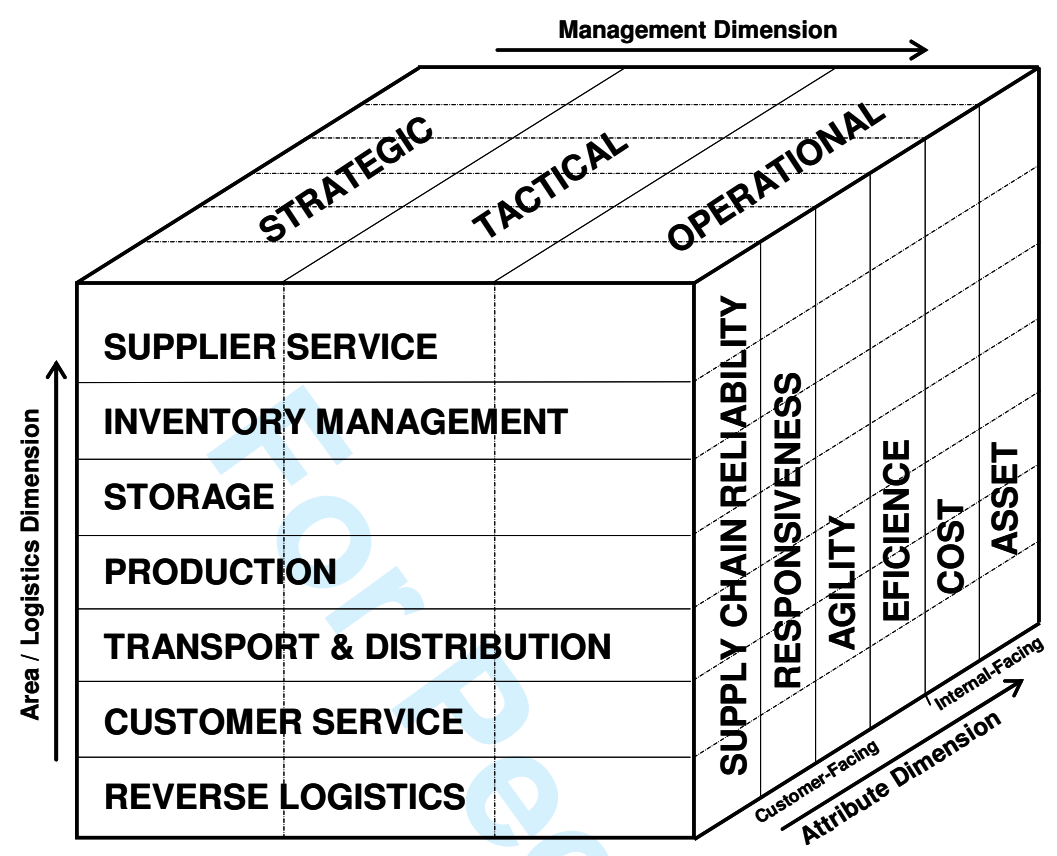


1

2

3

4

5

6

7

8

9

10

11

12

13

14

15

16

17

18

19

20

21

22

23

24

25

26

27

28

29

30

31

32

33

34

35

36

37

38

39

40

41

42

43

44

45

46

47

48

49

50

51

52

53

54

55

56

57

58

59

60

Figure 3. Example of a template for the AS-IS/TO-BE analysis

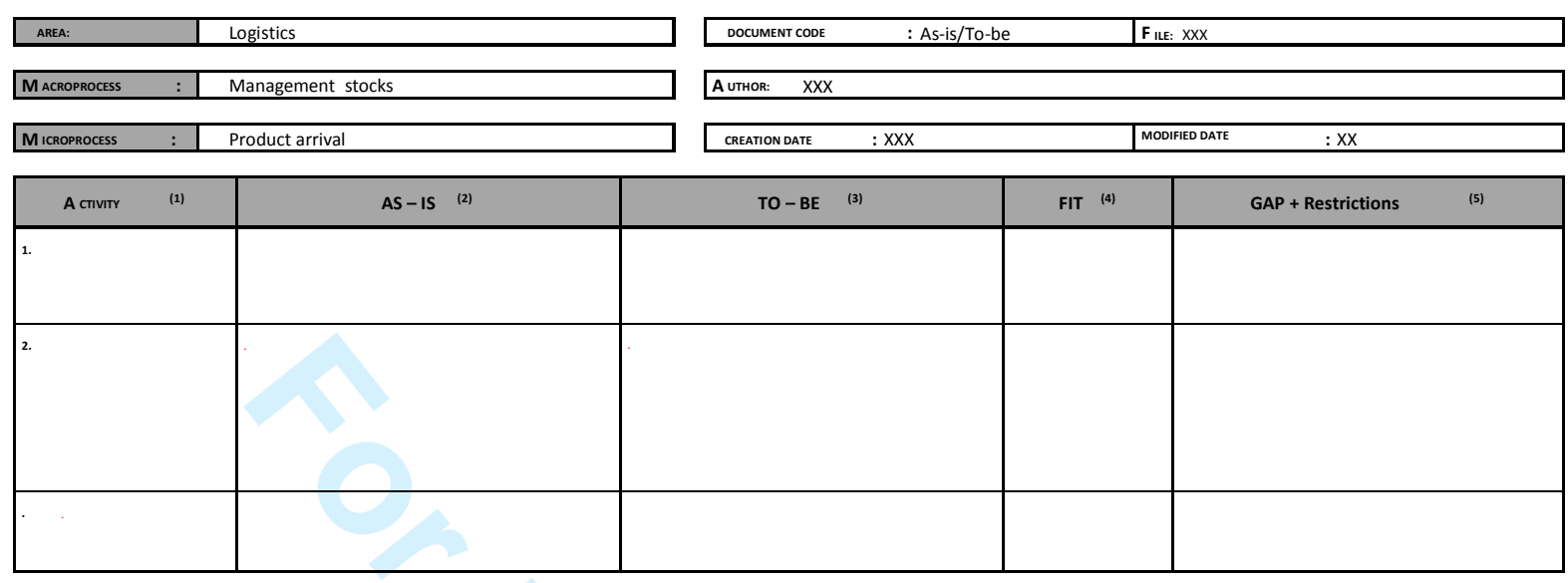

NOTES :

(1) The activity row must show the activities of the inter-enterprise business process model.

(2) Describes how the activity is carried out in the present.

(3) Describes how the activity must be carried out in the future.

(4) Should indicate:

- OK: if the activity is carried out at present in a desirable manner.

- NOT OK: if the activity is not carried out in a desirable way.

(5) Describes the differences between the TO-BE and the AS-IS, showing possible restrictions to go from the AS-IS to the TO-BE. 
Table 5. Significant benefits observed by the SMEs

\begin{tabular}{|c|c|}
\hline SIGNIFICANT BENEFITS OBSERVED & $\begin{array}{c}\% \\
\text { Observed }\end{array}$ \\
\hline - Generation of proactivity with regard to the process of SCI. & $100 \%$ \\
\hline $\begin{array}{l}\text { - Further performance improvements by defining a KPI identification model that fits the } \\
\text { characteristics of the way an SME works and agrees with its management needs. }\end{array}$ & $93.3 \%$ \\
\hline - Integration of tasks and shared information on the different levels of the supply chain. & $91.64 \%$ \\
\hline $\begin{array}{l}\text { - Collaboration and coordination of all the components of the supply chain to allow joint action } \\
\text { plans to be designed and carried out, so as to obtain coherent and synchronised planning that } \\
\text { responds promptly to market variations. }\end{array}$ & $91.09 \%$ \\
\hline $\begin{array}{l}\text { - Improvements in inventory management. On-line information about supplies in warehouses } \\
\text { made it possible to forecast production needs and to optimise stock management. }\end{array}$ & $89.94 \%$ \\
\hline $\begin{array}{l}\text { - Programming and follow-up of supply delivery dates, production times, and delivery times to } \\
\text { end customers, which ensures a greater capacity to react in order to cope with market demand. }\end{array}$ & $89.93 \%$ \\
\hline $\begin{array}{l}\text { - Significant improvements in both customer and supplier services, because knowing the status } \\
\text { of orders and creating synergies among them makes it possible to reduce all delivery times. }\end{array}$ & $87.64 \%$ \\
\hline $\begin{array}{l}\text { - Sales, purchases, warehousing and production departments can share and process information } \\
\text { simultaneously. Thus, members of sales staff will be able to provide customers with accurate } \\
\text { information about product availability; warehouse staff can search for products quickly and } \\
\text { simply; purchasing personnel have access to accurate real-time data so that optimal levels of } \\
\text { stock can be maintained and stock maintenance costs can be minimised, and so forth. }\end{array}$ & $87.43 \%$ \\
\hline $\begin{array}{l}\text { - Clear improvements in the productivity of the operational logistics system, which increased the } \\
\text { levels of customer service and made it possible to carry out actions that led to better } \\
\text { administration of operations and to the development of lasting relationships that were highly } \\
\text { beneficial to key suppliers and customers in their supply chain. }\end{array}$ & $86.98 \%$ \\
\hline $\begin{array}{l}\text { - Generation of a coordinated work flow to ensure the different areas of the components of the } \\
\text { chain work properly. }\end{array}$ & $86.59 \%$ \\
\hline $\begin{array}{l}\text { - Cutting costs. Integration of the supply chain allowed a drastic reduction in operating costs to be } \\
\text { achieved. }\end{array}$ & $84.39 \%$ \\
\hline $\begin{array}{l}\text { - Generate and identify new business opportunities which had previously either gone undetected } \\
\text { in each company or had not been detected because there was no collaboration among the } \\
\text { partners in the chain. }\end{array}$ & $80 \%$ \\
\hline - Lower the cost of labour & $19 \%$ \\
\hline - Cost of new product development & $16.6 \%$ \\
\hline - Product innovation lead time & $13.3 \%$ \\
\hline - Inc & $11 \%$ \\
\hline
\end{tabular}


Table 6. Some KPIs identified in the case study

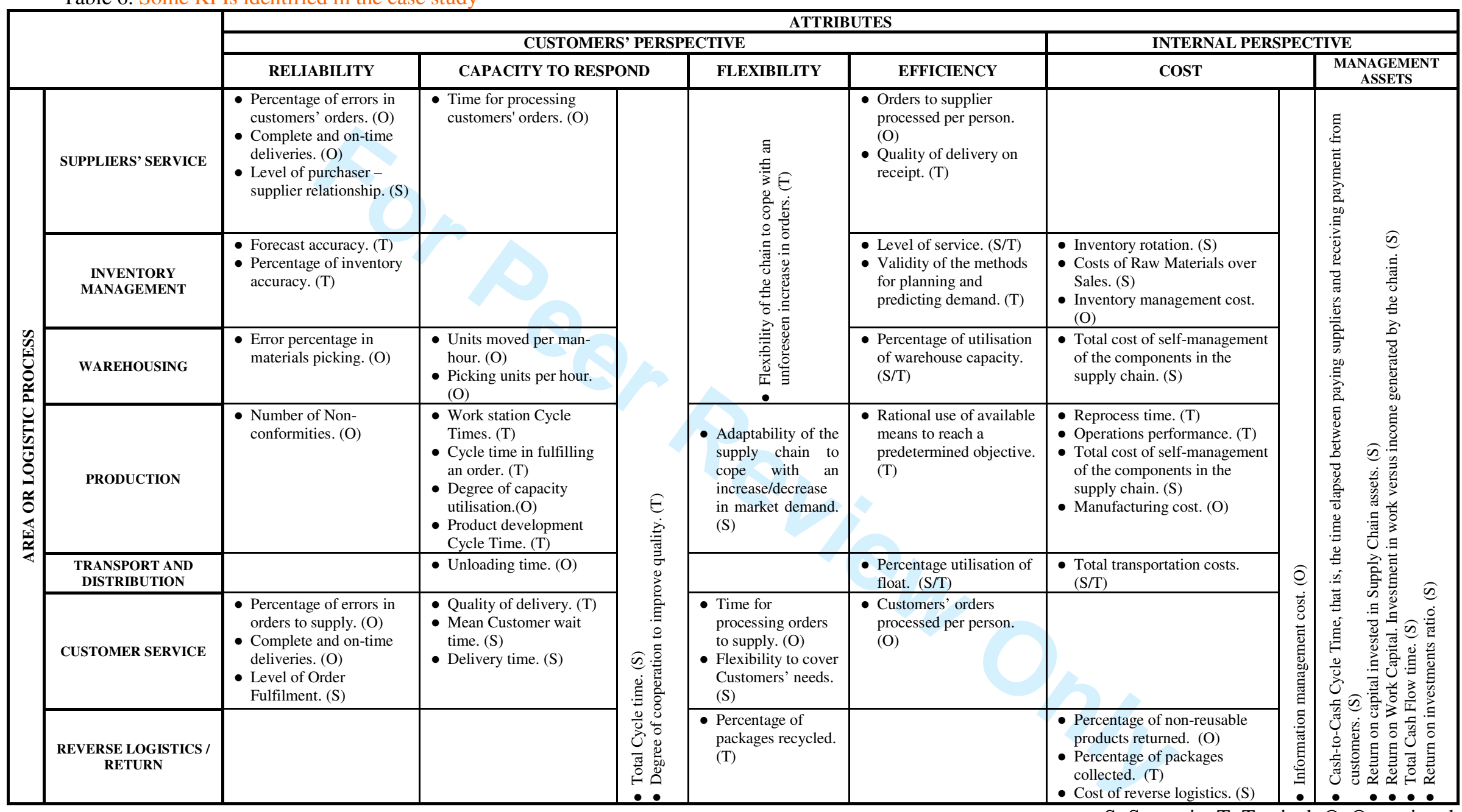

S: Strategic; T: Tactical; O: Operational 
Sergio Palomero Rodenas is currently associate professor at Department of Business Administration at the Universitat Jaume I in Castellón, Spain. He is a member of the Excellentia Research Group at this university. He earned a Master's Degree in Business Administration and a $\mathrm{PhD}$ in Industrial Engineering from the Universidad Politécnica de Valencia, Spain. He was Head of the Department of Production Engineering at the GEC-Alsthom Transport Factory in Valencia and was in charge of SAP installation in the production area of all the Spanish factories in the Alsthom Group. His research interests include Open Innovation, Enterprise Integration, Re-engineering, Information Systems, Electronic Commerce, Workflow Modelling and Simulation. 
Ricardo Chalmeta Rosaleñ is an associate professor in the Computer Science Department at the Universitat Jaume I in Castellón, Spain. He is Head of the Systems Integration research group (IRIS group) at this university. He received his BSc, MSc and $\mathrm{PhD}$ degrees in Computer Engineering from the Universidad Politécnica de Valencia, Spain. He has been invited as a researcher and lecturer by different universities in Australia, USA, Brazil, Germany, Peru or Bulgaria. He has served as a consultant in several manufacturing and transport firms, working on Enterprise Integration and Re-engineering activities and on the development of Integrated Information Systems. 


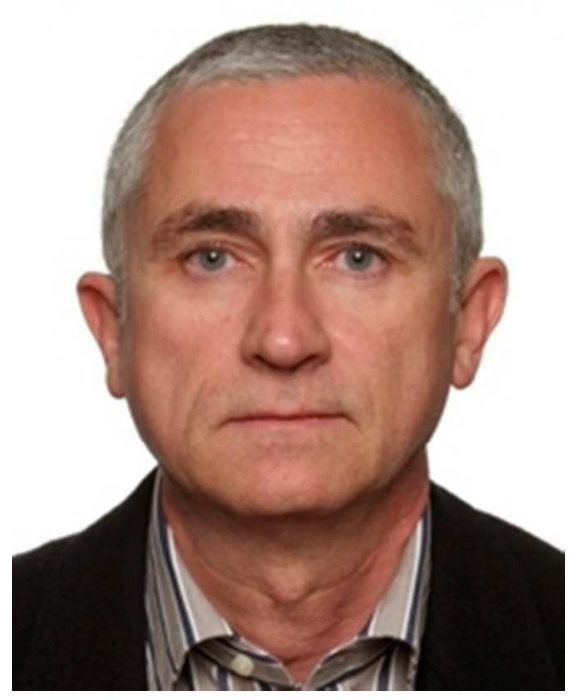

$21 \times 28 \mathrm{~mm}(254 \times 254 \mathrm{DPI})$ 


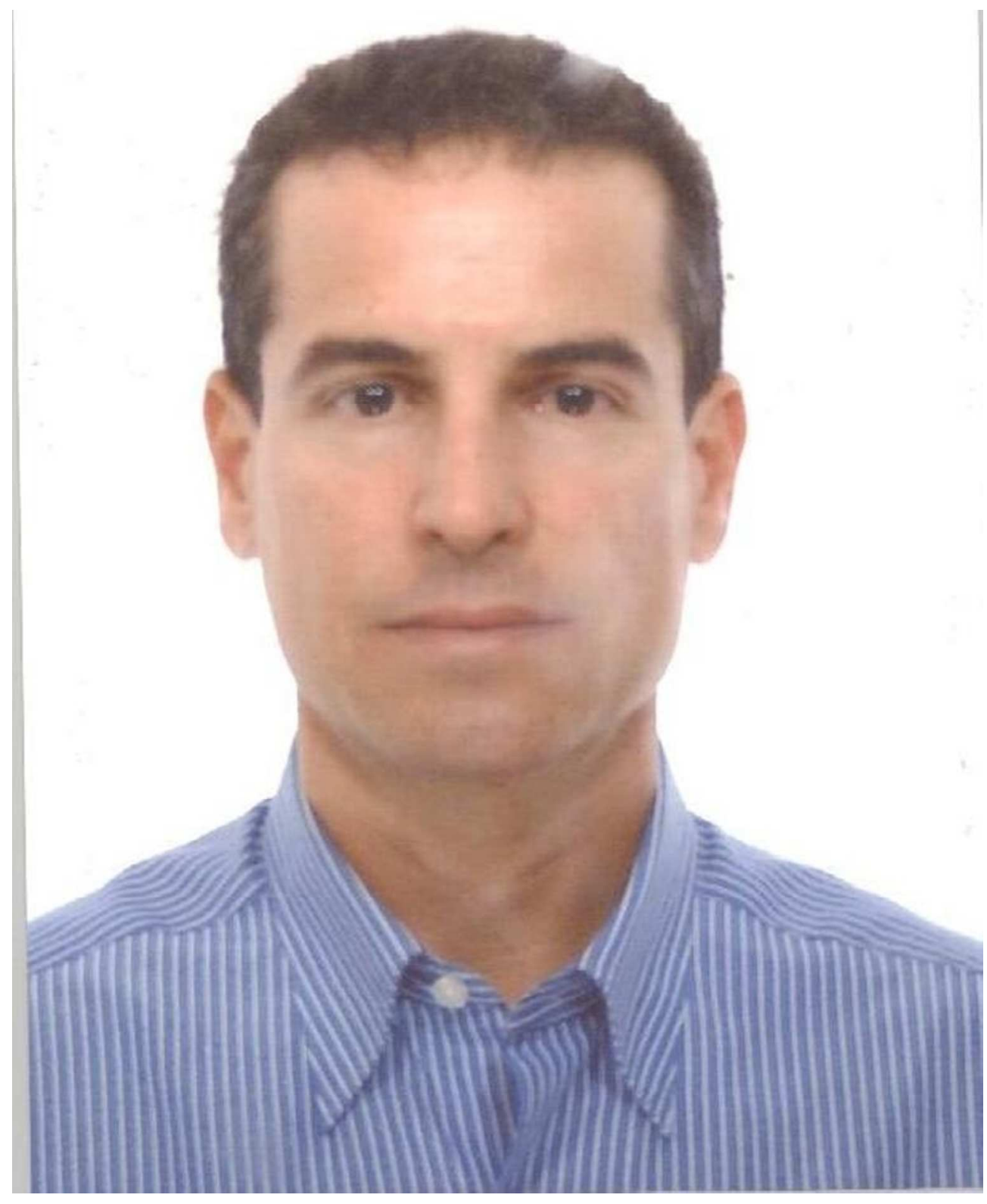

$160 \times 195 \mathrm{~mm}(96 \times 96 \mathrm{DPI})$ 